\title{
EM BUSCA DA COMPETITIVIDADE: COMPORTAMENTO ECONÔMICO E FINANCEIRO DE EMPRESAS DA CONSTRUÇÃO CIVIL LISTADAS NA BM\&FBOVESPA NO PERÍODO 2007-2016
}

\author{
Alex Eckert \\ Universidade de Caxias do Sul - UCS \\ Brasil \\ Anelise Pioner \\ Universidade de Caxias do Sul - UCS \\ Brasil \\ Marlei Salete Mecca \\ Universidade de Caxias do Sul - UCS \\ Brasil
}

Data de submissão: 07/02/2018

Data de aceite: $21 / 08 / 2018$

\section{RESUMO}

Este artigo teve por objetivo identificar se a evolução da economia brasileira impactou nas demonstrações contábeis das empresas analisadas. Em termos metodológicos, tratase de uma pesquisa, descritiva, qualitativa e quantitativa, de natureza documental. Para realização do estudo, foram utilizadas as demonstrações contábeis das empresas selecionadas no período para calcular quocientes de Liquidez Seca, Giro do Ativo, Rentabilidade do Ativo, Rentabilidade do Patrimônio Líquido e Endividamento. Através da análise, foi possível constatar os extremos econômicos e financeiros das empresas. Com base nas informações encontradas, comparou-se com a evolução da economia brasileira do período. A pesquisa também evidenciou os períodos de recessão e crescimento econômico na economia brasileira.

Palavras-Chave: Construção civil; Demonstrações contábeis; Análise das demonstrações contábeis; Análise de índices; Oscilações econômicas.

\section{LOOKING FOR COMPETITIVENESS: ECONOMIC AND FINANCIAL ANALYSIS OF CONSTRUCTION COMPANIES LISTED ON THE BRAZILIAN STOCK EXCHANGE BETWEEN 2007 AND 2016}

\section{ABSTRACT}

The objective of this research was to identify if the evolution of the Brazilian economy impacted on the financial statements of the companies analyzed. In methodological terms, it is a descriptive, qualitative and quantitative research, as well as a documentary 
type. To carry out the study, the financial statements of the companies selected in the period were used to calculate the Dry Liquidity, Asset Turning, Asset Profitability, Net Worth and Indebtedness quotients. Through the analysis, it was possible to verify the economic and financial extremes of the companies. Based on the information found, it was compared to the evolution of the Brazilian economy of the period. The research also showed the periods of recession and economic growth in the Brazilian economy.

Keywords: Civil construction; Accounting statements; Analysis of the financial statements; Index analysis; Economic oscillations.

\section{Introdução}

O setor da Construção Civil representa uma importante peça para a economia. Conforme IBGE (2017), no primeiro trimestre de 2017, o setor foi responsável por 7,7\% da participação relativa na População Ocupada Total. Para Castro (2012), o setor de construção civil é a área com maior capacidade de elevação de crescimento de produto, emprego e renda, em curto e médio prazo. $\mathrm{O}$ autor argumenta que com incentivos e programas governamentais, empresas da área absorvem mão de obra com pouco ou nenhuma formação, diminuindo as taxas de desemprego em momentos de crises econômicas. Além disso, o setor aumenta a demanda de inúmeros produtos e serviços.

O Brasil vem passando por um momento de instabilidade e a Construção Civil é um dos setores fortemente afetados. Para Amorim (2015), o setor está vivendo uma crise sem precedentes, com cerca de 600.000 demissões em 12 meses, recuo de 5,6\% nas vendas em 2014, em empresas de /capital aberto, queda de $98 \%$ do lucro no primeiro trimestre e perda de 12 bilhões de reais de valor de mercado na BM\&FBovespa no ano.

Schumpeter (1939) afirmou que os ciclos econômicos ocorrem em 4 fases: boom, recessão, depressão e recuperação. Considerando que os ciclos econômicos tendem a se repetir continuamente, estudá-los e assim, observar o comportamento das empresas à medida em que a economia flutua, é uma forma de obter informações a fim de, futuramente, suavizar os picos de crise.

A análise das Demonstrações Contábeis é importante, não apenas para acionistas e investidores, que tem interesse na rentabilidade e segurança de seus investimentos, segundo Greco, Gärtner e Arend (2009). As Demonstrações Contábeis também fornecem bases para análises macroeconômicas de regiões ou países, realizadas por economistas e o governo pode traçar políticas tributárias a partir das mesmas demonstrações.

Para os gestores, justifica-se o estudo pela necessidade de verificar resultados para que as empresas consigam manter a competitividade em períodos de flutuações econômicas. Porém, é importante que não se limitem apenas às Demonstrações Contábeis da organização de seu interesse. É necessário que se analise o contexto em que a empresa está inserida, como outras empresas do ramo e a macroeconomia.

Segundo Minsky (1992), uma economia capitalista que apresente um sistema financeiro sofisticado, complexo e em contínua evolução alterna períodos de comportamento estável com períodos turbulentos. Dessa maneira, busca-se através da 
análise do desempenho das empresas listadas na BM\&FBovespa no setor de Construção Civil entre 2007 e 2016, obter diagnósticos a fim de fundamentar e conduzir decisões nesse período de incertezas.

Com isto, o presente estudo tem por objetivo identificar o comportamento econômico e financeiro de empresas na atividade de Construção Civil listadas na BM\&FBovespa à medida que a economia brasileira se movimenta no período de $2007 \mathrm{a}$ 2016.

Para elaboração deste estudo foi feito, inicialmente, um levantamento bibliográfico. Após, foram analisados os índices econômicos e financeiros das empresas listadas na BM\&FBovespa no setor de Construção Civil. Para dar prosseguimento ao estudo, os índices de desenvolvimento econômico-financeiros das empresas atuantes na atividade de construção civil foram comparados com as oscilações econômicas brasileiras no período entre 2007 e 2016. Para finalizar, foi avaliado se o setor pode ter contribuído em períodos de crescimento e recessão econômica no país.

\section{Referencial Teórico}

\subsection{A Contabilidade e seus principais relatórios}

A essência da Contabilidade é o estudo e controle do patrimônio de toda e qualquer entidade, podendo ser pública ou privada, com fins lucrativos ou não. Segundo Iudícibus et al. (2011, p. 1), Contabilidade é a ciência social aplicada com metodologia para captar, registrar, acumular, resumir e interpretar os fenômenos que afetam situações patrimoniais, financeiras e econômicas.

A partir de atos e fatos contábeis, são geradas informações que possibilitam ao usuário a avaliação da situação patrimonial da instituição, bem como, analisar variações econômicas e financeiras ocorridas no período avaliado (GRECO; AREND, 2011, p. 2). Tais informações são mostradas em relatórios específicos.

Hall (2012) afirma que os objetivos das informações são específicos de empresa para empresa, conforme a necessidade do usuário. No entanto, três objetivos são fundamentais. Primeiramente, fornece suporte à gestão empresarial, auxiliando a gerir adequadamente os recursos da empresa e relatar suas atividades. Além disso, apoia a tomada de decisões gerenciais, contribuindo no planejamento e controle de decisões relativas à sua área de responsabilidade. Por fim, sustenta operações diárias da empresa, amparando a execução eficiente e eficaz de tarefas diárias.

Em termos de padronização da apresentação dos relatórios contábeis, o Brasil segue as Normas Internacionais de Contabilidade - IFRS. As especificações são regidas, principalmente, pelo CPC 00-R1, que trata da Estrutura Conceitual para Elaboração e Divulgação de Relatório Contábil-Financeiro (CPC, 2011a), e pelo CPC 26-R1, cujo enfoque é a Apresentação das Demonstrações Contábeis (CPC,2011b). Dentre os principais relatórios contábeis, pode-se citar o Balanço Patrimonial, a Demonstração de Resultados do Exercício, a Demonstração dos Lucros e Prejuízos Acumulados, a Demonstração das Mutações do Patrimônio Líquido, a Demonstração de Fluxos de Caixa, a Demonstração do Valor Adicionado, além das Notas Explicativas.

Para Perez Junior e Begalli (2009, p. 9), o Balanço Patrimonial - BP evidencia a estrutura patrimonial da empresa, onde consta: ativo, passivo e patrimônio líquido. $\mathrm{O}$ ativo representa a aplicação dos recursos em bens, direitos e valores a receber pela entidade. Já o passivo, demonstra a fonte dos recursos aplicados no ativo. É onde 
constam todas as obrigações da empresa com terceiros. Por fim, o patrimônio líquido apresenta a real riqueza, os recursos próprios da instituição. Aritmeticamente, é a diferença entre o ativo e o passivo.

Por outro lado, a Demonstração de Resultados do Exercício - DRE apresenta o conjunto de receitas, despesas e o resultado do período. De acordo com Greco e Arend (2011), a receita consiste em valores que a empresa recebeu ou tem direito a receber, não necessariamente provenientes de sua atividade principal. Ao contrário das receitas, as despesas são gastos, bens ou serviços, entendidos como necessários, para a atividade da empresa. O resultado é a diferença entre Receitas e Despesas, podendo ser Lucro, quando receitas são maiores que despesas ou Prejuízo, quando despesas são maiores do que receitas.

Já a Demonstração dos Lucros e Prejuízos Acumulados (DLPA) consiste em evidenciar o saldo inicial, as mutações ocorridas e o saldo final de lucros ou prejuízos em determinado período. Conforme Braga (2009, p. 96), a demonstração sinaliza de qual forma o lucro foi destinado, em caso de lucro no período analisado e em caso de prejuízo, demonstra se e por qual gênero de reserva foi absorvido.

A Demonstração das Mutações do Patrimônio Líquido - DMPL tem o mesmo objeto de evidenciação que a DLPA, portanto, a lei societária permite a substituição da DLPA pela DMPL, visto que é mais completa. Segundo Braga (2009), a DMPL além de evidenciar as modificações ocorridas no Patrimônio Líquido no período, permite também a identificação das causas de evolução ou involução.

Para Iudícibus et al. (2011), a Demonstração de Fluxos de Caixa - DFC deve estar compatível com o fluxo de caixa, visto que é demonstrada por regime de caixa. $\mathrm{O}$ que a difere do DRE, que é demonstrado por regime de competência, e por isso, não é conciliável com o fluxo de caixa. A DFC tem três subdivisões: fluxo de caixa das atividades operacionais, das atividades de investimento e das atividades de financiamento.

Segundo Braga (2009), as atividades operacionais apresentam entradas e saídas de caixa provenientes da operação da empresa. Apresentam também se a empresa tem capacidade de quitar suas obrigações e fazer novos investimentos sem recorrer a terceiros. No que se refere ao fluxo das atividades de investimento, o autor considera que representam pagamentos e recebimentos ligados à realizável a longo prazo (RLP), investimentos, imobilizado, intangível, diferido renda fixa e renda variável. Por fim, o fluxo das atividades de financiamento, que consistem em recebimentos e pagamentos ligados à passivos e patrimônio líquido.

Já a Demonstração do Valor Adicionado - DVA evidencia o valor agregado aos fatores de produção, ou seja, quanto gerou de riqueza e de que forma essa riqueza foi distribuída ou reinvestida. Segundo Ribeiro (2011), o valor adicionado consiste na diferença entre o valor da receita de vendas e os custos dos recursos adquiridos de terceiros. Os dados são obtidos principalmente da DRE, porém as duas demonstrações não podem ser confundidas.

Para Santos (2006), a DRE apresenta em sua linha final apenas o lucro líquido, uma vez que a DVA demonstra o valor destinado aos sócios, aos demais capitalistas que financiaram a empresa, aos empregados e ao governo. Diferentemente da DRE, onde os componentes são apresentados de acordo com a natureza, na DVA os componentes são exibidos de acordo com os beneficiários da renda.

As Demonstrações Contábeis citadas anteriormente devem ser complementadas com as Notas Explicativas - NE. Ribeiro (2011, p. 110) destaca que as 
NE objetivam facilitar a interpretação dos dados que compõem as demonstrações financeiras, como critérios de avaliação utilizados pela empresa, composição de saldos, o método de depreciação, etc.

Com base nas Demonstrações Contábeis apuradas pelas empresas, é possível desenvolver a análise de balanços. De acordo com Assaf Neto (2015), a análise das Demonstrações Contábeis visa a apresentação da posição econômico-financeira atual, a passada e a futura (projetada), podendo ser analisada de diferentes formas para atender as necessidades do interessado, sendo ele investidor, credor, concorrente, governo, entre outros.

Segundo Iudícibus et al. (2011), sócios, acionistas e proprietários de quotas societárias tem interesse em analisar a rentabilidade e a segurança de seus investimentos. Já administradores, diretores e executivos tem interesse nas análises para fins de tomada de decisão com maior segurança.

Por outro lado, os fornecedores são usuários externos, que segundo Assaf Neto (2015), buscam obter informações sobre a capacidade de pagamento da empresa. Da mesma forma, bancos procuram conhecer a posição a curto e longo prazo sociedade. Já os concorrentes compreender melhor seu mercado em relação ao setor de atividade. Cabe mencionar ainda o governo, que com a intenção de formular políticas econômicas, tem a necessidade de conhecer a posição financeira de diversos setores.

Ainda de acordo com o ponto de vista de Assaf Neto (2015), a análise de balanços se torna mais consistente quando interpretada juntamente com seu mercado de atuação. Deve ser examinado o potencial do mercado consumidor, o nível e o tamanho da concorrência, a dependência tecnológica, os fornecedores e a política de preços do setor de atividade em que a empresa está inserida.

\subsection{Análise através de indicadores}

Conforme Braga (2009), a análise de liquidez tem o objetivo de avaliar a capacidade de financiamento da empresa em relação a suas exigibilidades. A análise interna de liquidez constitui-se num dos mais valiosos instrumentos de controle financeiros, especialmente quando realizada em períodos curtos (semanais, quinzenais, mensais). $\mathrm{O}$ autor considera ainda que a liquidez é o principal parâmetro para julgar a conveniência de um empréstimo a curto prazo, pois apresenta a capacidade da empresa de pagar suas contas. Se a liquidez não tiver cobertura suficiente, a empresa poderá não pagar suas obrigações em dia.

A liquidez geral (LG) considera a situação a longo prazo da empresa, não se limitando apenas ao circulante. Para Ribeiro (2011, p. 161), a LG demonstra se o capital aplicado no AC e no RLP são suficientes para liquidar as obrigações totais, mostrando quanto a empresa tem de AC e RLP para cada $\mathrm{R} \$ 1,00$ de obrigações.

Para Lins (2012), esse indicador demonstra quanto a empresa tem de ativos para cada real de obrigações com terceiros. Quando o indicador é menor do que 1,00, mostra uma possível tendência da empresa à insolvência, sendo que, quanto menor o indicador, pior é a situação a curto e longo prazo.

No entendimento de Braga (2009), o quociente verifica quantas unidades monetárias a empresa possui para cada unidade de sua dívida a curto prazo, isto é, visa a avaliação da capacidade da empresa de pagar suas obrigações a curto prazo. Assaf Neto (2015) resume a interpretação da LC no Quadro 1: 
Quadro 1 - Resumo da Interpretação da LC

$$
\begin{array}{ll}
\text { Se: } & \text { Denota: } \\
\text { Liquidez Corrente }>1,0 & \text { Capital Circulante Líquido positivo } \\
\text { Liquidez Corrente }=1,0 & \text { Capital Circulante Líquido nulo } \\
\text { Liquidez Corrente }<1,0 & \text { Capital Circulante Liquido negativo }
\end{array}
$$

Fonte: ASSAF NETO (2015, pg. 188)

Portanto, ainda conforme Assaf Neto (2015), a LC representa a relação entre ativo circulante (AC) e passivo circulante (PC), ou seja, quanto existe de AC para cada $\mathrm{R} \$ 1,00$ de PC. Com isso, conclui-se que quanto maior o índice, se superior a 1,00, maior será a folga de capital no caso de a empresa precisar liquidar todas as suas obrigações a curto prazo, isto é, quanto maior o quociente, melhor.

Para Padoveze e Benedicto (2007), a liquidez seca (LS) é uma extensão da LC, pois mostra a capacidade de quitar as dívidas de curto prazo utilizando o AC, excluindose os estoques. O estoque é retirado do cálculo devido à maior dificuldade de se transformar em dinheiro em razão de que é necessário produzir e vender para, posteriormente, haver o recebimento.

Saporito (2015) descreve a LS como a quantidade de reais a receber em até 360 dias, desconsiderando os estoques, para cada real de passivo no mesmo prazo. Isso resulta numa mensuração mais rigorosa da capacidade de pagamento ao curto prazo, já que os estoques são desconsiderados devido ao maior risco visto que estão sujeitos a perdas por avaria, roubo, desvalorização e obsolescência, além da dificuldade de venda.

Iudícibus (2011) descreve o quociente de liquidez imediata como o quanto que a empresa dispõe imediatamente para quitar dívidas a curto prazo. Para Marion (2012), em questões de análises, o índice de liquidez imediata é pouco importante devido à grande variação de vencimentos, embora a curto prazo. O índice pode ser mantido como limite de segurança, mas não como base, pois os valores representados como Caixa e Equivalentes de Caixa perdem o poder aquisitivo com a inflação.

Quocientes de rentabilidade são resultantes da confrontação do lucro periódico com outros elementos das Demonstrações Contábeis. Iudícibus (2010) afirma que quocientes de rentabilidade são quocientes que oferecem maior segurança para análises por remeter aos períodos ao invés de datas específicas.

Segundo Ribeiro (2011, p. 168), os quocientes de rentabilidade evidenciam a capacidade econômica da empresa, ou seja, demonstram o resultado econômico obtido pelo capital investido. Para Silva (2007), esse indicador representa a relação entre vendas do período e investimentos totais realizados na empresa, demonstrando a produtividade dos investimentos totais.

Para Assaf Neto (2015), o Giro do Ativo (GA) representa o número de vezes que o ativo total da empresa se transformou em dinheiro durante determinado período em relação às vendas realizadas. Ribeiro (2011, p. 170) caracteriza a Margem Líquida (ML) como "Quanto a empresa obteve de Lucro Líquido para cada \$ 1 vendido", ou seja, qual a margem de lucratividade em relação ao faturamento. Quanto maior o índice, maiores serão os Lucros obtidos pela empresa. 
Já Saporito (2015) caracteriza a ML como a porção das Vendas Líquidas que a empresa conseguiu preservar após descontar todas as despesas necessárias para o funcionamento da empresa.

Braga (2012) descreve a Rentabilidade do Ativo como o quociente que evidencia em quanto tempo que o montante de investimentos operacionais deverá retornar à empresa. Quanto menor for índice, menor será o tempo de recuperação do investimento e maior será a capacidade da empresa em gerar lucros operacionais.

Para Lins e Francisco Filho (2012), o quociente indica o quanto a empresa obtém de Lucro para cada real investido em ativo, ou seja, apresenta o lucro alcançado na utilização de seus ativos. Iudícibus (2010) acredita que entre os quocientes de rentabilidade, a rentabilidade do Patrimônio Líquido é o mais significativo, pois expõe a rentabilidade em relação à participação dos sócios da empresa, evidenciando o retorno sobre o investimento dos sócios.

Saporito (2015) explica a rentabilidade do Patrimônio Líquido como a taxa de retorno aos acionistas da empresa, pois é calculada com o Lucro Líquido, que consiste na "sobra" das receitas totais após serem efetuadas todas as despesas necessárias. O autor avalia esse índice de forma que, quanto maior for o resultado, melhor. Para Lins e Francisco Filho (2012), os Indicadores de Estrutura Patrimonial avaliam a composição financeira da empresa, ou seja, medem a participação de capital de terceiros e de capital próprio em relação ao passivo da empresa.

Já Saporito (2015), afirma que Índices de Estrutura avaliam dois diferentes aspectos. O primeiro se refere a decisões financiamento e o outro, apresenta quanto os investimentos permanentes comprometem seus recursos próprios

Para Perez Junior e Begalli (2009), o índice indica a participação do capital de terceiros na atividade da empresa. Taxas de encargos financeiros podem influenciar a interpretação desse indicador, assim como grau de alavancagem dos mesmos. O autor ainda analisa que quanto maior o índice, maior é a dependência de capital de terceiros. Segundo Assaf Neto (2015), o Grau de Endividamento apresenta a relação entre as dívidas de curto e longo prazo e o patrimônio líquido, evidenciando o quanto a empresa tomou de empréstimo para cada R \$ 1,00 de capital próprio aplicado.

\subsection{Oscilações econômicas e a construção civil}

Para Claessens, Kose e Terrones (2011), nas últimas duas décadas, o mercado financeiro tem sido influenciado por oscilações econômicas que têm ocasionado grandes colapsos e recessões, desta forma, entender os ciclos financeiros se tornou imprescindível.

Nesta mesma perspectiva, Borio (2012) afirma que não existe consenso na definição de ciclos financeiros. Para ele, são booms seguidos de recessões que se repetem de tempos em tempos. Tais interações podem ampliar flutuações econômicas, causando dificuldades financeiras.

Segundo Andersen (2013), crises são parte do sistema financeiro desde os primórdios e são tão grandes, globais e complexas que é ingênuo pensar que podem ser evitadas. Em uma análise das crises financeiras ocorridas nos últimos 30 anos, o autor sustenta que as crises têm em comum a regulamentação deficiente, Contabilidade desonesta, mentalidades de rebanho e sentimento de infalibilidade.

Andersen (2013) ainda argumenta que as crises estão destinadas a se repetir devido à forma que os mercados funcionam. Quanto maior a bolha, maiores serão os preços e por consequência, ocorrerá o aumento na taxa de juros. Após o boom, a 
tendência é a regulamentação, porém essa alternativa não evita que outras situações impulsionem outra crise.

No que diz respeito à crise imobiliária estadunidense ocorrida em 2008, Bresser-Pereira (2009) afirma que a principal causa da crise foi a concessão irresponsável de empréstimos hipotecários para credores que não tinham condições de pagar no momento ou quando a taxa de juros subisse. Além disso, agentes financeiros recorreram às irresponsáveis 'inovações financeiras", agravando a crise.

Segundo D'Almeida (2011), para evitar a repetição do crash de 1929, o governo estadunidense interviu na economia. Em 2008, o Governo Bush criou um fundo administrado pelo Tesouro Americano visando compra pelo de ações e de ativos problemáticos de instituições financeiras e foram implantadas medidas fiscais de estímulo à economia. Em 2009, o Governo Obama aumentou os gastos do governo e cortou impostos da classe média, além de ajudar os mutuários residenciais que corriam o risco de perder suas casas.

Para Moreira (2010), das consequências da crise de 2008, uma delas foi agravar a dívida soberana de alguns países da Zona do Euro, os chamados PIIGS (Portugal, Irlanda, Itália, Grécia e Espanha), tendo a Grécia como a situação mais crítica. Estes países com altos índices de endividamento e déficit fiscal tem duas saídas, desvalorização cambial ou calote, como estão na Zona do Euro, não é possível mexer no câmbio, deixando o medo do calote ficar mais presente. Uma das medidas tomadas para recuperar as economias fragilizadas na Zona do Euro foi a criação de fundos de empréstimos e linhas que permitem acesso a recursos em dólar.

No Brasil, de acordo com Torres, Puga e Meirelles (2011), o impacto da crise norte-americana foi amenizado com medidas anticíclicas que contribuíram para a recuperação da economia, como desoneração tributária de alguns materiais de construção, expansão de crédito para habitação e aumento de recursos para o Programa de Aceleração do Crescimento.

No que diz respeito à indústria da construção, Hillebrandt (2000) afirma que é a indústria cujo produtos e serviços são necessários para construção de edifícios e obras duráveis. A atividade abrange novas construções, modificações, reparações e demolição de edifícios e obras de engenharia civil, envolvendo também montagem e instalação de pré-fabricados em obras e edifícios. Devido à diversidade da indústria da construção, para certos fins, é conveniente dividi-la em subsetores.

As autoras ainda justificam a importância do setor apresentando que por meio da instalação de portos, ferrovias, rodovias, sistemas de irrigação, energia e comunicação, ou seja, serviços indispensáveis para o setor primário, secundário e terciário, a construção facilita o desenvolvimento de outras atividades econômicas.

Claessens, Kose e Terrones (2011) identificaram um total de 473 ciclos econômicos completos entre 1960 e 2007, sendo 114 relacionados à habitação. O ciclo de valores de residências costuma ser mais longo e mais nítido do que os ciclos de crédito, por exemplo.

Ainda sobre a importância do setor, o Quadro 2 apresenta a evolução de dados gerais do setor entre 2013 e 2014.

Quadro 2 - Dados Gerais da Indústria da Construção - Brasil 


\begin{tabular}{|c|c|c|c|c|c|c|c|c|}
\hline \multirow[b]{3}{*}{ Ano } & \multicolumn{8}{|c|}{ Dados gerais da Indústria da Construção } \\
\hline & \multirow{2}{*}{$\begin{array}{c}\text { № de } \\
\text { empresas } \\
\text { ativas } \\
\end{array}$} & \multirow{2}{*}{$\begin{array}{l}\text { Pessoal } \\
\text { Ocupado }\end{array}$} & $\begin{array}{l}\text { Salários, } \\
\text { Retiradas } \\
\text { e Outras } \\
\text { Remun. }\end{array}$ & $\begin{array}{l}\text { Gastos de } \\
\text { pessoal } \\
\text { total }\end{array}$ & $\begin{array}{l}\text { Incorp. } \\
\text { Obras e/ou } \\
\text { Serviços }\end{array}$ & $\begin{array}{l}\text { Total dos } \\
\text { Custos e } \\
\text { Despesas }\end{array}$ & $\begin{array}{l}\text { Construções } \\
\text { para } \\
\text { Entidades } \\
\text { Públicas }\end{array}$ & $\begin{array}{l}\text { Receita } \\
\text { Bruta Total }\end{array}$ \\
\hline & & & \multicolumn{6}{|c|}{$1.000 .000 \mathrm{R} \$$} \\
\hline 2007 & 52.870 & 1.575 .883 & 19.359 & 28.979 & 130.093 & 97.988 & 50.968 & 133.577 \\
\hline 2008 & 57.102 & 1.806 .258 & 25.718 & 38.725 & 163.109 & 128.755 & 68.607 & 166.691 \\
\hline 2009 & 63.829 & 2.053 .443 & 31.928 & 48.390 & 197.702 & 153.972 & 82.943 & 201.818 \\
\hline 2010 & 76.308 & 2.430 .119 & 41.716 & 62.881 & 255.603 & 207.241 & 102.746 & 260.668 \\
\hline 2011 & 93.375 & 2.658 .643 & 49.735 & 74.551 & 284.115 & 232.609 & 105.028 & 291.713 \\
\hline 2012 & 104.534 & 2.858 .180 & 60.890 & 91.332 & 336.376 & 270.744 & 114.977 & 336.412 \\
\hline 2013 & 110.713 & 2.936 .499 & 67.160 & 101.946 & 355.257 & 288.295 & 116.937 & 361.437 \\
\hline 2014 & 119.018 & 2.852 .824 & 73.197 & 106.621 & 381.992 & 311.844 & 128.225 & 389.192 \\
\hline
\end{tabular}

Fonte: IBGE (2017).

Em 2015, o setor de construção civil foi responsável por 6,4\% do PIB Nacional, mantendo a média histórica conforme mostra o Quadro 3, correspondente à participação da Construção Civil (em \%) no Valor Adicionado a Preços Básicos do país:

Quadro 3 - Participação (\%) do PIB da Construção Civil no PIB Total Brasil - 2000 a 2015

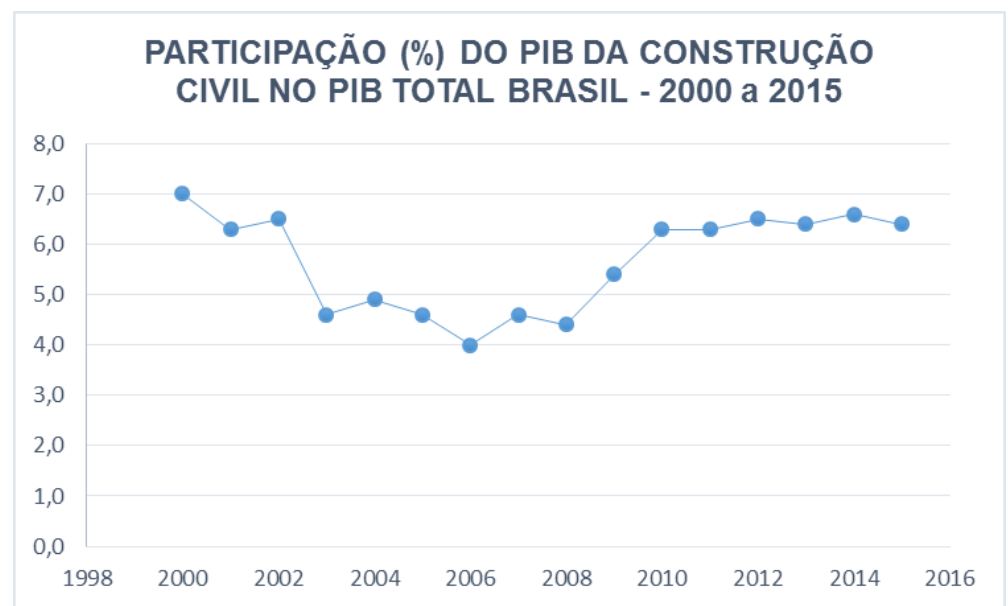

Fonte: IBGE (2017), Diretoria de Pesquisas, Coordenação de Contas Nacionais

Segundo Torres, Puga e Meirelles (2011), o setor da construção civil brasileira tem como característica o intenso uso de mão de obra não qualificada, assim como mão de obra informal. A utilização de empregos informais não é considerada nos resultados pelo Instituto Brasileiro de Geografia e Estatística (IBGE), dessa forma, subestimando a contribuição do setor para formação de empregos e renda na sociedade brasileira.

Nessa mesma perspectiva, o Quadro 4 apresenta a porcentagem de pessoas empregadas formalmente no setor de construção no período de janeiro de 2007 a dezembro de 2015 em seis regiões metropolitanas (Recife, Salvador, Belo Horizonte, Rio de Janeiro, São Paulo e Porto Alegre). 


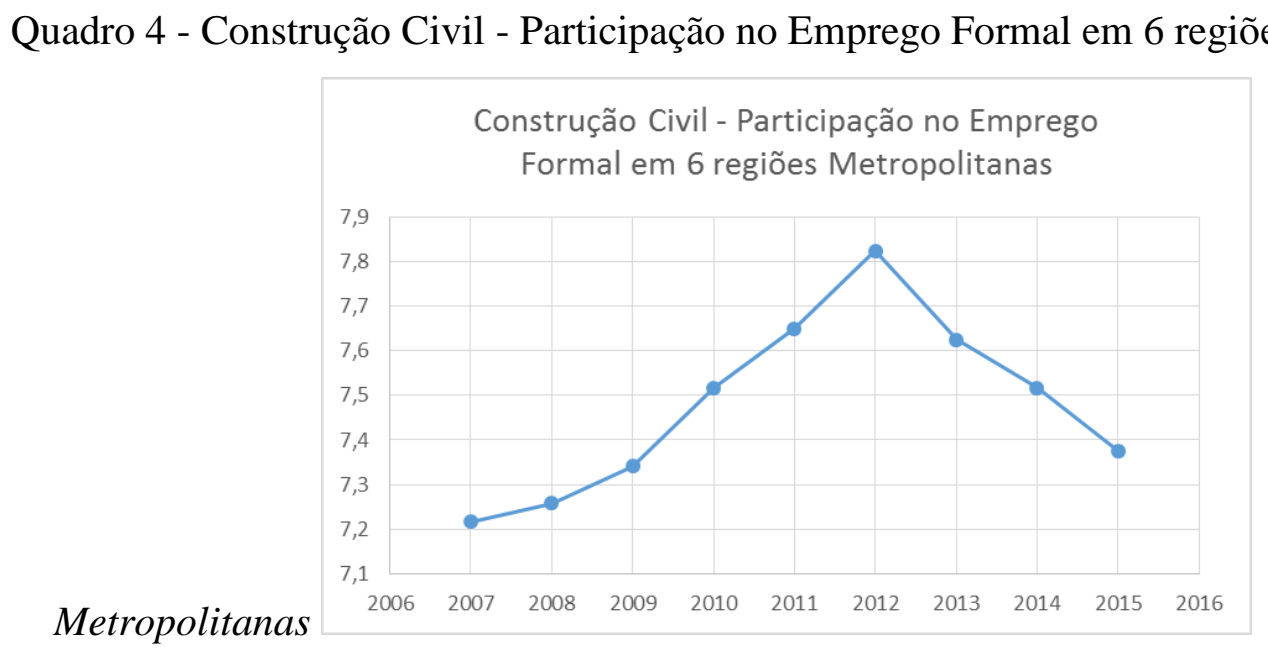

Fonte: IBGE (2017).

O gráfico apresenta a menor porcentagem de participação no emprego formal nas 6 regiões metropolitanas pesquisadas em 2007, onde pessoas ocupadas na Construção Civil representou 7,2\%. Já a maior porcentagem registrada no período, foi em 2012, onde pode-se notar um aumento de $0,6 \%$, atingindo $7,8 \%$.

\section{Metodologia}

Para o desenvolvimento dessa pesquisa, a metodologia utilizada quanto aos objetivos é a pesquisa descritiva. Para Marion et al. (2010), a pesquisa descritiva busca observar, quantificar, descrever e classificar. A pesquisa visa descrever o contexto, privilegiando o processo ao resultado, buscando captar a evolução do ocorrido.

Quanto aos procedimentos, a metodologia utilizada é a pesquisa documental. De Acordo com Michel (2009), a pesquisa documental é realizada com documentos pessoais e ou institucionais produzidos por pessoas ou instituições da população definida na metodologia proposta para a pesquisa.

No que diz respeito à forma de abordagem do problema, a pesquisa é quantitativa e qualitativa. A pesquisa quantitativa consiste em fundamentar dados objetivos passíveis de mensuração, conforme afirma Ramos (2009). Já a pesquisa qualitativa, de acordo com Michel (2009), é utilizada quando o pesquisador encontra fenômenos que, em face de sua complexidade, é de difícil quantificação. É apropriada para a compreensão contextual do caso estudado.

Para os objetivos propostos na presente pesquisa, inicialmente foram coletadas, diretamente no site da BM\&FBovespa, as demonstrações contábeis das empresas do ramo de Construção Civil relativas ao período 2007-2016. Na sequência, as informações provenientes desses relatórios foram tabuladas manualmente utilizando o software Excel. Posteriormente, os quocientes escolhidos utilizando embasamento teórico foram calculados, dos quais se extraiu os indicadores escolhidos para a pesquisa. Por fim, foi realizada a análise dos resultados encontrados. 


\section{Realização da pesquisa e análises}

\subsection{Amostra das empresas selecionadas}

Para esta pesquisa, foram selecionadas empresas listadas na BM\&FBovespa no setor de atuação Consumo Cíclico, que segundo D’Andréa (2012), consiste em empresas que possuem número de demanda e oferta cíclicos, ou seja, em determinados períodos, o desempenho melhor. Para Rocha (2015), empresas de consumo cíclico são empresas em que macroeconomia exerce forte influência sobre a atividade operacional.

Dentro do setor de Consumo Cíclico, a pesquisa foi direcionada para o subsetor de Construção Civil, e então, delimitada para as empresas do segmento de Edificações. Em 2016, 17 empresas pertenciam a este grupo.

Por fim, o estudo foi restrito apenas às empresas que dentro do segmento supracitado, tiveram Demonstrações Contábeis publicadas em todos os anos entre 2007 e 2016. Assim, das 17 empresas, apenas uma não teve suas Demonstrações Contábeis publicadas no período, restando 16 empresas. O Quadro 5 apresenta as Companhias selecionadas para a presente pesquisa. 
Em busca da competitividade: comportamento econômico e financeiro de empresas da construção civil listadas na BM\&FBovespa no período 2007-2016

\begin{tabular}{|c|c|c|c|c|}
\hline Número & Identificação & Razão Social & Sede & Histórico \\
\hline 01 & Adolpho & $\begin{array}{l}\text { Construtora } \\
\text { Adolpho } \\
\text { Lindenberg S.A }\end{array}$ & SP & $\begin{array}{l}\text { Constituída em } 13 \text { de julho de 1962, executa e administra obras de construção } \\
\text { civil em geral, serviços de empreitada e incorporações de empreendimentos } \\
\text { imobiliários. Em 2008, LDI Desenvolvimento Imobiliário AS adquire o controle da } \\
\text { Companhia. (BM\&FBOVESPA, 2017; CONSTRUTORA ADOLPHO } \\
\text { LINDENBERG, 2017) }\end{array}$ \\
\hline 02 & CR2 & \begin{tabular}{|l|} 
CR2 \\
Empreendimentos \\
Imobiliários S.A
\end{tabular} & RJ & $\begin{array}{l}\text { Constituída em } 10 \text { de janeiro de 2006, atua no Rio de Janeiro e em São Paulo. } \\
\text { Opera formando parcerias para cada um de seus projetos. (BM\&FBOVESPA, } \\
\text { 2017; CR2 EMPREENDIMENTOS IMOBILIÁRIOS S.A) }\end{array}$ \\
\hline 03 & Cyrela & $\begin{array}{l}\text { Cyrela Brazil } \\
\text { Realty S.A } \\
\text { Empreend e Part }\end{array}$ & SP & $\begin{array}{l}\text { Fundada em } 1962 \text { em São Paulo, atua integrando construção, vendas e serviços } \\
\text { no segmento de alto padrão e luxo. (BM\&FBOVESPA, 2017; CYRELA BRAZIL } \\
\text { REALTY S.A EMPREEND E PART, 2017) }\end{array}$ \\
\hline 04 & Direcional & $\begin{array}{l}\text { Direcional } \\
\text { Engenharia S.A }\end{array}$ & $M G$ & $\begin{array}{l}\text { Fundada em } 19 \text { de fevereiro de } 1981 \text { em Belo Horizonte, obteve registro de } \\
\text { companhia aberta na CVM m } 29 \text { de fevereiro de 2008. Atua na incorporação e } \\
\text { construção de empreendimentos populares, bem como, orgãos públicos. } \\
\text { (BM\&FBOVESPA, 2017; DIRECIONAL ENGENHARIA S.A, 2017) }\end{array}$ \\
\hline 05 & Even & $\begin{array}{l}\text { Even Construtora } \\
\text { e Incorporadora } \\
\text { S.A }\end{array}$ & SP & $\begin{array}{l}\text { Constituída em 2002, atua nos Estados do Rio de Janeiro, Minas Gerais, São } \\
\text { Paulo e Rio Grande do Sul no segmento de empreendimentos residenciais e } \\
\text { comerciais. (BM\&FBOVESPA, 2017; EVEN CONSTRUTORA E } \\
\text { INCORPORADORA S.A, 2017) }\end{array}$ \\
\hline 06 & EZ TEC & $\begin{array}{l}\text { EZ TEC Empreend } \\
\text { e Participações } \\
\text { S.A }\end{array}$ & SP & $\begin{array}{l}\text { Criada em } 15 \text { de fevereiro de 1979, iniciou sua operação na BM\&Fbovespa em } 27 \\
\text { de junho de 2007. Atua essencialmente na Região Metropolitana de São Paulo } \\
\text { incorporando e construindo empreendimentos residenciais e comerciais. } \\
\text { (BM\&FBOVESPA, 2017; EZ TEC EMPREEND E PARTICIPAÇÕES S.A, 2017) }\end{array}$ \\
\hline 07 & Gafisa & Gafisa S.A & SP & $\begin{array}{l}\text { Fundada em 1954, atua na incorporação e construção de empreendimentos } \\
\text { comerciais e residenciais. Primeira empresa do setor listada na Bolsa de Nova } \\
\text { lorque (NYSE). (BM\&FBOVESPA, 2017; GAFISA S.A, 2017) }\end{array}$ \\
\hline 08 & Helbor & \begin{tabular}{|l|} 
Helbor \\
Empreendimentos \\
S.A
\end{tabular} & SP & $\begin{array}{l}\text { Fundada em } 1977 \text { por Hélio Borenstein, um imigrante russo. Atua focada na } \\
\text { gestão do processo imobiliário, além da comercialização das unidades. } \\
\text { (BM\&FBOVESPA, 2017; HELBOR EMPREENDIMENTOS S.A, 2017) }\end{array}$ \\
\hline 09 & JHSF & \begin{tabular}{|l} 
JHSF \\
Participações S.A
\end{tabular} & SP & $\begin{array}{l}\text { Criada em 1972, possui capital aberto desde 2007. Consolidou atuação em São } \\
\text { Paulo, Salvador e Manaus e opera no ramo de Shoppings, Incorporações, Hotéis } \\
\text { \& Restaurantes Fasano e Aeroporto Executivo. (BM\&FBOVESPA, 2017; JHSF } \\
\text { PARTICIPAÇÕES S.A, 2017) }\end{array}$ \\
\hline 10 & João Fortes & $\begin{array}{l}\text { João Fortes } \\
\text { Engenharia S.A }\end{array}$ & RJ & $\begin{array}{l}\text { Constituída em 1950, executou prédios e superquadras residenciais e } \\
\text { comerciais, sedes empresariais, shopping centers, hospitais, universidades, } \\
\text { entre outras construções e incorporações. (BM\&FBOVESPA, 2017; JOÃO } \\
\text { FORTES ENGENHARIA S.A, 2017) }\end{array}$ \\
\hline 11 & MRV & $\begin{array}{l}\text { MRV Engenharia } \\
\text { e Participações } \\
\text { S.A }\end{array}$ & $M G$ & $\begin{array}{l}\text { Fundada em } 1979 \text { em Belo Horizonte, atua no setor de construção de edifícios } \\
\text { residenciais. Hoje é a maior parceira do programa Minha Casa Minha Vida. } \\
\text { (BM\&FBOVESPA, 2017; MRV ENGENHARIA E PARTICIPAÇÕES S.A, 2017) }\end{array}$ \\
\hline 12 & PDG & $\begin{array}{l}\text { PDG Realty S.A } \\
\text { Empreend e } \\
\text { Participações }\end{array}$ & SP & $\begin{array}{l}\text { Constituída em } 17 \text { de novembro de } 1998 \text { em São Paulo, em } 2007 \text { foi realizada a } \\
\text { abertura do capital. Investe em empreendimentos imobiliários através de co- } \\
\text { incorporação e portfólio para Classe Média e Média Baixa. (BM\&FBOVESPA, } \\
\text { 2017; PDG REALTY S.A EMPREEND E PARTICIPAÇÕES, 2017) }\end{array}$ \\
\hline 13 & Rodobens & $\begin{array}{l}\text { Rodobens } \\
\text { Negócios } \\
\text { Imobiliários S.A }\end{array}$ & SP & $\begin{array}{l}\text { Rodobens Engenharia transformou-se em Robobens Negócios Imobiliários em } \\
1991 \text { após } 8 \text { anos construindo galpões e concessionárias para as Empresas } \\
\text { Rodobens. Em 2007, abriu seu capital da bolsa de valores. (BM\&FBOVESPA, } \\
\text { 2017; RODOBENS NEGÓCIOS IMOBILIÁRIOS S.A, 2017) }\end{array}$ \\
\hline 14 & Rossi & $\begin{array}{l}\text { Rossi Residencial } \\
\text { S.A }\end{array}$ & SP & $\begin{array}{l}\text { Fundada em } 1980 \text { com foco na incorporação de imóveis residenciais de alto } \\
\text { padrão, passou a atuar também nos segmentos voltados à classe média e baixa, } \\
\text { projetos urbanísticos, Shopping Centers e loteamentos. Desde 2008, suas ações } \\
\text { integram a BM\&Fbovespa. (BM\&FBOVESPA, 2017; ROSSI RESIDENCIAL S.A, }\end{array}$ \\
\hline 15 & Tecnisa & Tecnisa S.A & SP & $\begin{array}{l}\text { Criada em } 22 \text { de setembro de 1977, passou a ser listada na BM\&Fbovespa em 10 } \\
\text { de fevereiro de } 2007 \text {. Atua na incorporação, compra e venda de imóveis prontos e } \\
\text { a construir, locação e administração de bens imóveis, construção de imóveis e } \\
\text { prestação de serviço de consultoria imobiliária. (BM\&FBOVESPA, 2017; } \\
\text { TECNISA S.A, 2017) }\end{array}$ \\
\hline 16 & Viver & $\begin{array}{l}\text { Viver } \\
\text { Incorporadora e } \\
\text { Construtora S.A }\end{array}$ & SP & $\begin{array}{l}\text { Constituída em 1992, negocia ações na BM\&Fbovespa desde 2007. Atua em } \\
\text { todas as etapas da incorporação imobiliária, desde a aquisição do terreno à } \\
\text { venda das unidades de empreendimentos do padrão econômico ao altíssimo } \\
\text { padrão no segmento residencial, comercial, de turismo e loteamentos. } \\
\text { (BM\&FBOVESPA, 2017; VIVER INCORPORADORA E CONSTRUTORA S.A, } \\
\text { 2017) }\end{array}$ \\
\hline
\end{tabular}

Elaboração: autores 
Chama atenção no Quadro 6 que muitas empresas têm sua sede em São Paulo, sendo 11 de 16 empresas. Além disso, observa-se que são empresas com muitos anos de atuação no mercado, a mais antiga, João Fortes, foi fundada em 1950, ou seja, em 2017 completa 67 anos de sua fundação. Ainda é possível constatar que as empresas atuam em diversas áreas da administração de obras e construção civil, além de imóveis residenciais.

Neste tópico, serão realizadas as pesquisas com os principais índices (ou quocientes) econômicos e financeiros, com a finalidade de analisar a situação das empresas no período selecionado.

Para Iudícibus (2010), o uso de quocientes visa permitir ao analista extrair tendências e comparar quocientes com padrões preestabelecidos. Mais do que retratar o que aconteceu no passado, a finalidade da análise é fornecer informações para interferir o que acontecerá no futuro.

\subsection{Cálculo dos Índices}

Neste tópico, serão realizadas as pesquisas com os principais índices (ou quocientes) econômicos e financeiros, com a finalidade de analisar a situação das empresas no período selecionado.

Para Iudícibus (2010), o uso de quocientes visa permitir ao analista extrair tendências e comparar quocientes com padrões preestabelecidos. Mais do que retratar o que aconteceu no passado, a finalidade da análise é fornecer informações para interferir o que acontecerá no futuro.

\subsubsection{Liquidez Seca}

Segundo Braga (2009), a liquidez é o principal parâmetro para julgar a conveniência de um empréstimo a curto prazo. Isso se deve pois evidencia a capacidade de financiamento da organização em relação a suas exigibilidades. Para encontrá-lo, utilizou-se a fórmula "Ativo Circulante - Estoques / Passivo Circulante".

Dentre os índices de liquidez possíveis para realizar este estudo, a autora optou pela Liquidez Seca, visto que, segundo Braga (2009), como os prazos dependem de diversos fatores para sua realização, os quais estão sujeitos a situações como retração de mercado, perecimento, obsolescência, etc., alguns analistas preferem eliminar os estoques do Ativo Circulante com a finalidade de apurar se a companhia tem condições de atender suas dívidas a curto prazo sem contar com seus estoques. O Quadro 6 apresenta o quociente de Liquidez Seca encontrado nos últimos 10 anos das empresas selecionadas: 
Quadro 6 - Índices de Liquidez Seca Calculados

\begin{tabular}{|c|c|c|c|c|c|c|c|c|c|c|c|}
\hline & $\mathbf{2 0 0 7}$ & $\mathbf{2 0 0 8}$ & $\mathbf{2 0 0 9}$ & $\mathbf{2 0 1 0}$ & $\mathbf{2 0 1 1}$ & $\mathbf{2 0 1 2}$ & $\mathbf{2 0 1 3}$ & $\mathbf{2 0 1 4}$ & $\mathbf{2 0 1 5}$ & $\mathbf{2 0 1 6}$ & MÉDIA \\
\hline Adolpho & 0,91 & 0,38 & 0,16 & 0,16 & 0,27 & 0,57 & 1,19 & 1,61 & 2,14 & 2,31 & $\mathbf{0 , 9 7}$ \\
\hline CR2 & 3,76 & 2,39 & 1,16 & 1,57 & 1,43 & 1,50 & 2,03 & 3,36 & 4,33 & 5,40 & $\mathbf{2 , 6 9}$ \\
\hline Cyrela & 0,97 & 0,95 & 1,57 & 1,30 & 1,36 & 1,57 & 1,61 & 1,38 & 1,73 & 1,87 & $\mathbf{1 , 4 3}$ \\
\hline Direcional & 0,98 & 2,03 & 3,95 & 2,19 & 2,09 & 2,48 & 2,76 & 2,31 & 2,66 & 2,27 & $\mathbf{2 , 3 7}$ \\
\hline Even & 2,66 & 2,70 & 2,90 & 2,18 & 2,35 & 3,13 & 2,76 & 2,42 & 2,10 & 1,95 & $\mathbf{2 , 5 1}$ \\
\hline EZ TEC & 3,73 & 4,12 & 3,20 & 2,90 & 2,70 & 2,36 & 2,70 & 1,57 & 2,71 & 2,74 & $\mathbf{2 , 8 7}$ \\
\hline Gafisa & 1,67 & 1,57 & 1,80 & 2,55 & 1,15 & 1,71 & 1,58 & 1,32 & 1,19 & 1,00 & $\mathbf{1 , 5 5}$ \\
\hline Helbor & 3,20 & 1,83 & 1,15 & 1,62 & 1,33 & 1,41 & 1,63 & 1,21 & 1,38 & 1,04 & $\mathbf{1 , 5 8}$ \\
\hline JHSF & 3,48 & 1,35 & 1,61 & 2,43 & 1,98 & 2,89 & 2,53 & 1,20 & 0,85 & 1,15 & $\mathbf{1 , 9 5}$ \\
\hline João Fortes & 0,38 & 0,81 & 0,80 & 1,12 & 1,01 & 1,09 & 0,79 & 0,76 & 0,95 & 0,73 & $\mathbf{0 , 8 4}$ \\
\hline MRV & 1,93 & 1,90 & 2,10 & 1,77 & 1,50 & 1,35 & 1,61 & 1,37 & 1,34 & 1,38 & $\mathbf{1 , 6 2}$ \\
\hline PDG & 2,41 & 1,33 & 1,59 & 1,79 & 1,72 & 1,85 & 1,53 & 1,16 & 0,48 & 0,26 & $\mathbf{1 , 4 1}$ \\
\hline Rodobens & 3,08 & 1,80 & 1,24 & 1,40 & 2,33 & 1,88 & 2,16 & 1,99 & 2,05 & 1,88 & $\mathbf{1 , 9 8}$ \\
\hline Rossi & 1,22 & 1,29 & 1,77 & 1,73 & 1,73 & 1,44 & 0,91 & 0,65 & 0,45 & 0,43 & $\mathbf{1 , 1 6}$ \\
\hline Tecnisa & 1,69 & 1,55 & 1,73 & 1,53 & 1,68 & 1,13 & 1,42 & 1,09 & 0,80 & 0,57 & $\mathbf{1 , 3 2}$ \\
\hline Viver & 1,10 & 0,84 & 1,15 & 1,62 & 1,22 & 0,69 & 1,08 & 0,74 & 0,52 & 0,35 & $\mathbf{0 , 9 3}$ \\
\hline Média & $\mathbf{2 , 0 7}$ & $\mathbf{1 , 6 8}$ & $\mathbf{1 , 7 4}$ & $\mathbf{1 , 7 4}$ & $\mathbf{1 , 6 2}$ & $\mathbf{1 , 6 9}$ & $\mathbf{1 , 7 7}$ & $\mathbf{1 , 5 1}$ & $\mathbf{1 , 6 1}$ & $\mathbf{1 , 5 8}$ & $\mathbf{1 , 7 0}$ \\
\hline
\end{tabular}

Fonte: elaborado pelos autores

No Quadro 6, é possível perceber que, apesar de grande parte dos valores serem semelhantes, alguns destoam do restante dos resultados encontrados. É o caso da empresa CR2 em 2016, que apresentou uma Liquidez Seca de 5,40, ou seja, para cada $\mathrm{R} \$ 1,00$ de dívidas no Passivo Circulante, a empresa dispõe de R \$ 5,40 em bens, sem contar com o estoque, para quitar suas obrigações.

A Liquidez Seca encontrada em 2016 na empresa CR2 se deve ao fato de ter baixos valores de Estoques e Passivo Circulante em comparação com o Ativo Circulante. Os valores registrados em Estoque no Ativo Circulante são de apenas 37\% do total de $\mathrm{R} \$ 130.492 .000,00$ encontrados na soma das Unidades Concluídas e Terrenos em posse na empresa em 31/12/2016.

Nos anos de 2009 e 2010, os valores de Liquidez Seca encontrados na empresa Adolpho Lindenberg também se sobressaem, porém pelos baixos índices de 0,16 em ambos os anos. Isso ocorre pois até 2008, antes da Companhia ser adquirida pela Lindencorp Desenvolvimento Imobiliário S.A (LDI), a empresa possuía reduzido número de contratos, sendo insuficientes em relação às suas obrigações. Após a aquisição, a empresa passou por um processo de reestruturação operacional e administrativa, gerando caixa oriundo de suas atividades operacionais e assim, aumentando sua Liquidez Seca ano após ano, chegando à 2,31 em 2016.

Ao se considerar a média dos índices, percebe-se uma diferença significativa entre a maior e menor Liquidez Seca Média por empresa. Os extremos pertencem às empresas EZ TEC e João Fortes, com índices de 2,87 e 0,84 respectivamente, sendo a maior média $242 \%$ maior do que a menor, como mostra a Figura 1: 
Figura 1 - Liquidez Seca Média por Empresa

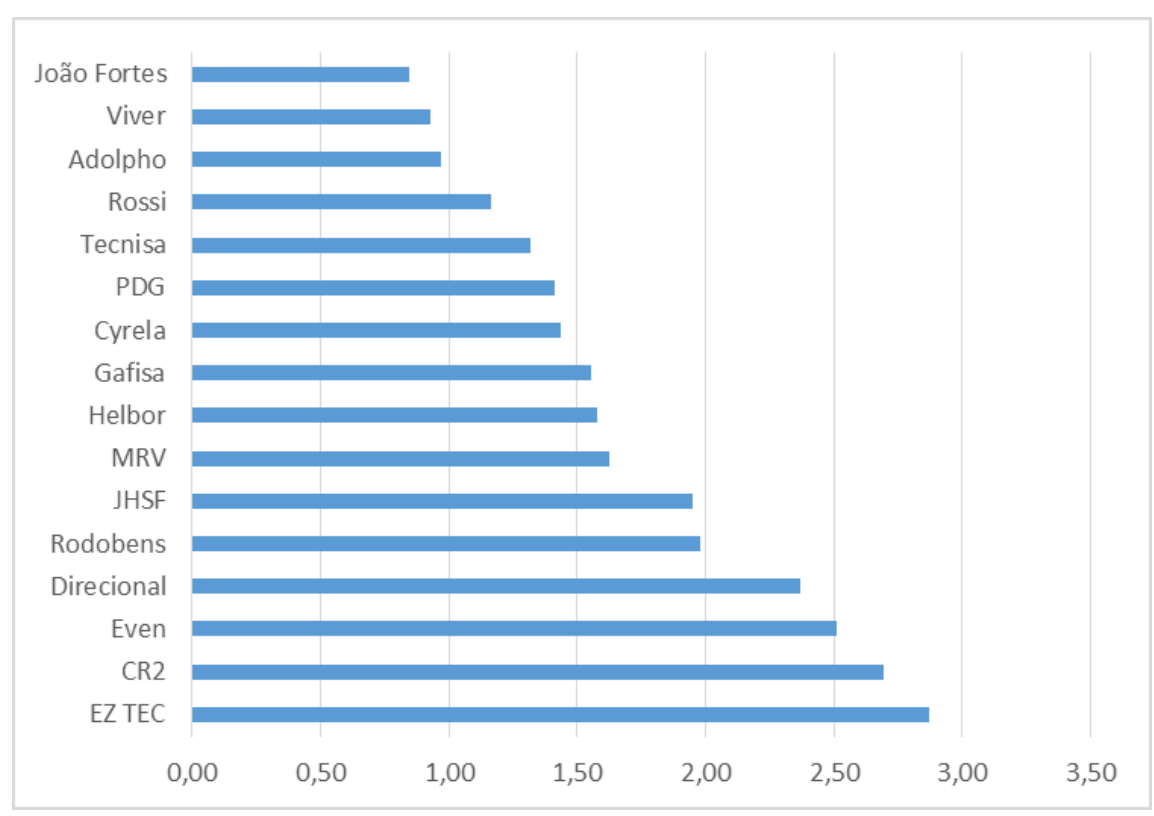

Fonte: elaborado pelos autores

A empresa João Fortes manteve sua Liquidez Seca próxima à 1 ao longo dos anos avaliados. Em 2007, teve seu menor índice de Liquidez Seca, de 0,38. Ao longo desse ano, a empresa passou por uma reestruturação e renovação interna, além da aprovação de grupamento de ações na proporção de 20 ações existentes para uma nova ação ordinária visando maior liquidez. Dessa forma, resultando em 2008, um índice de Liquidez Seca $113 \%$ maior do que no ano anterior.

Já a Companhia EZ TEC apresentou uma média de 2,87, a maior das empresas avaliadas nos últimos 10 anos. Em 2008, no primeiro sinal de escassez de crédito e redução de atividade econômica no EUA, a empresa alinhou uma gestão conservadora de caixa, garantindo assim, uma Liquidez Seca de 4,12, a maior no período analisado. Em consequência dessa tomada de decisão, a empresa obteve conforto financeiro para entregar os empreendimentos lançados e lançar novos.

Por outro lado, ao se observar as médias anuais da Liquidez Seca, é possível perceber que praticamente todos os valores estão entre 1,50 e 2,00, com exceção do ano de 2007, onde encontra-se um resultado de 2,07, a maior média dos últimos 10 anos, como pode-se observar na Figura 2: 
Figura 2 - Liquidez Seca (média anual)

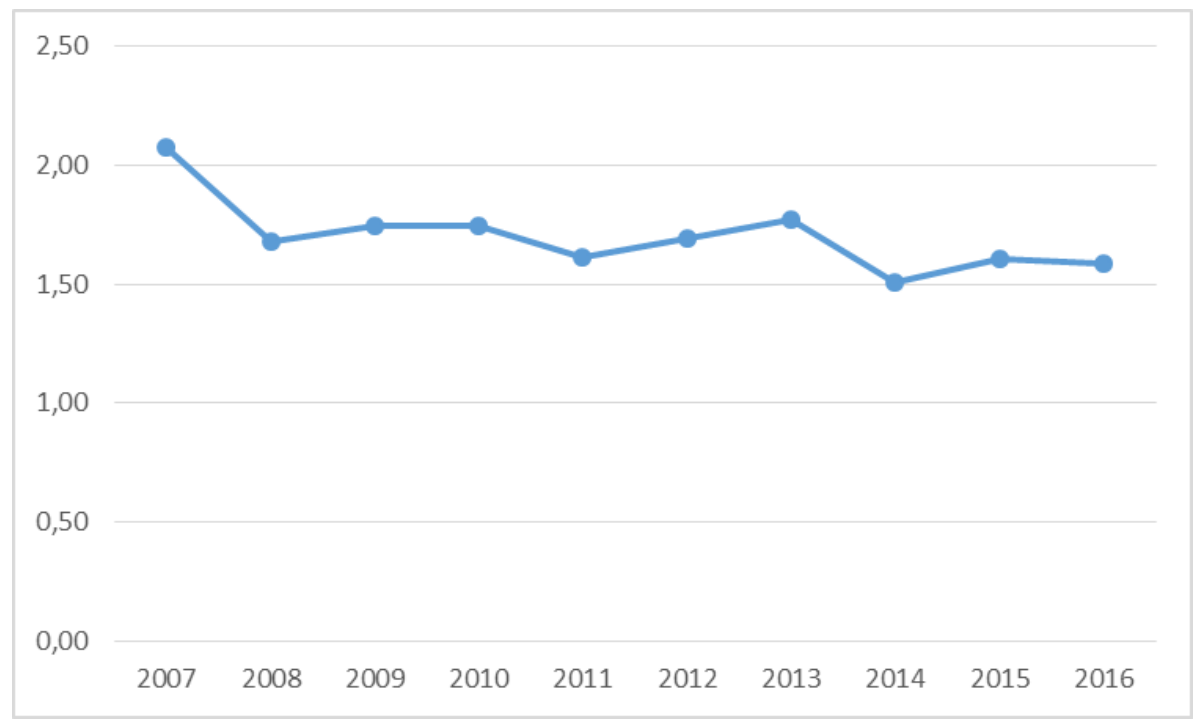

Fonte: elaborado pelos autores

Segundo o G1 (2007), o ano de 2007 foi marcado como um dos melhores na economia brasileira, tendo recordes na Bolsa de Valores e expansão do crédito e do setor imobiliário. Por outro lado, no mesmo ano, o Brasil começou a sentir o início da crise no mercado imobiliário do EUA, o que pode ter ocasionado numa diminuição brusca de Liquidez Seca nas empresas analisadas de 2007 para 2008.

Outro índice que chama atenção, é o resultado de 2014, o mais baixo do período analisado, de 1,51. Segundo Jornal do Brasil (2014), apesar da economia estadunidense ter apresentado melhora e a Copa do Mundo ter estimulado parte da economia brasileira, em 2014, o Brasil apresentou uma recessão técnica, que pode ter acarretado numa queda de Liquidez Seca das empresas analisadas.

\subsubsection{Giro do Ativo}

Para analisar a capacidade econômica da empresa, será utilizado o Giro do Ativo, que conforme Ribeiro (2011), evidencia a proporção existente entre o volume de vendas e os investimentos realizados na companhia, verificando se o volume de vendas no período está adequado em relação ao capital investido.

Para encontrá-lo, utilizou-se a fórmula "Vendas Líquidas / Ativo Total". O Quadro 7 evidencia os valores encontrados no cálculo do Giro do Ativo nos 10 anos estudados: 
Quadro 7 - Índices de Giro do Ativo calculados

\begin{tabular}{|c|c|c|c|c|c|c|c|c|c|c|c|}
\hline & $\mathbf{2 0 0 7}$ & $\mathbf{2 0 0 8}$ & $\mathbf{2 0 0 9}$ & $\mathbf{2 0 1 0}$ & $\mathbf{2 0 1 1}$ & $\mathbf{2 0 1 2}$ & $\mathbf{2 0 1 3}$ & $\mathbf{2 0 1 4}$ & $\mathbf{2 0 1 5}$ & $\mathbf{2 0 1 6}$ & Média \\
\hline Adolpho & 0,32 & 0,29 & 0,59 & 0,71 & 1,30 & 1,79 & 1,24 & 1,02 & 0,83 & 0,64 & $\mathbf{0 , 8 7}$ \\
\hline CR2 & 0,11 & 0,41 & 0,40 & 0,53 & 0,25 & 0,23 & 0,19 & 0,05 & 0,10 & 0,07 & $\mathbf{0 , 2 3}$ \\
\hline Cyrela & 0,42 & 0,38 & 0,35 & 0,41 & 0,45 & 0,41 & 0,37 & 0,43 & 0,34 & 0,27 & $\mathbf{0 , 3 8}$ \\
\hline Direcional & 0,46 & 0,45 & 0,35 & 0,47 & 0,44 & 0,46 & 0,51 & 0,46 & 0,40 & 0,33 & $\mathbf{0 , 4 3}$ \\
\hline Even & 0,40 & 0,47 & 0,51 & 0,64 & 0,49 & 0,57 & 0,51 & 0,45 & 0,43 & 0,35 & $\mathbf{0 , 4 8}$ \\
\hline EZ TEC & 0,20 & 0,36 & 0,45 & 0,46 & 0,42 & 0,31 & 0,40 & 0,28 & 0,25 & 0,16 & $\mathbf{0 , 3 3}$ \\
\hline Gafisa & 0,40 & 0,31 & 0,41 & 0,38 & 0,31 & 0,32 & 0,30 & 0,22 & 0,21 & 0,18 & $\mathbf{0 , 3 0}$ \\
\hline Helbor & 0,37 & 0,37 & 0,56 & 0,47 & 0,39 & 0,42 & 0,37 & 0,32 & 0,26 & 0,17 & $\mathbf{0 , 3 7}$ \\
\hline JHSF & 0,25 & 0,43 & 0,27 & 0,36 & 0,36 & 0,21 & 0,13 & 0,10 & 0,10 & 0,08 & $\mathbf{0 , 2 3}$ \\
\hline João Fortes & 0,26 & 0,25 & 0,47 & 0,50 & 0,35 & 0,22 & 0,29 & 0,25 & 0,18 & 0,09 & $\mathbf{0 , 2 9}$ \\
\hline MRV & 0,21 & 0,41 & 0,38 & 0,44 & 0,44 & 0,37 & 0,38 & 0,39 & 0,42 & 0,34 & $\mathbf{0 , 3 8}$ \\
\hline PDG & 0,22 & 0,38 & 0,33 & 0,34 & 0,38 & 0,26 & 0,32 & 0,27 & 0,17 & 0,05 & $\mathbf{0 , 2 7}$ \\
\hline Rodobens & 0,17 & 0,39 & 0,32 & 0,32 & 0,31 & 0,48 & 0,35 & 0,36 & 0,33 & 0,24 & $\mathbf{0 , 3 3}$ \\
\hline Rossi & 0,37 & 0,43 & 0,34 & 0,46 & 0,42 & 0,26 & 0,28 & 0,23 & 0,23 & 0,11 & $\mathbf{0 , 3 1}$ \\
\hline Tecnisa & 0,30 & 0,35 & 0,33 & 0,45 & 0,35 & 0,28 & 0,39 & 0,34 & 0,34 & 0,11 & $\mathbf{0 , 3 2}$ \\
\hline Viver & 0,13 & 0,34 & 0,25 & 0,31 & 0,20 & 0,10 & 0,26 & 0,10 & 0,09 & $-0,02$ & $\mathbf{0 , 1 8}$ \\
\hline Média & $\mathbf{0 , 2 9}$ & $\mathbf{0 , 3 8}$ & $\mathbf{0 , 3 9}$ & $\mathbf{0 , 4 5}$ & $\mathbf{0 , 4 3}$ & $\mathbf{0 , 4 2}$ & $\mathbf{0 , 3 9}$ & $\mathbf{0 , 3 3}$ & $\mathbf{0 , 2 9}$ & $\mathbf{0 , 2 0}$ & $\mathbf{0 , 3 6}$ \\
\hline
\end{tabular}

Fonte: elaborado pelos autores

No Quadro 8, pode-se perceber que a grande maioria dos valores encontrados são semelhantes, com poucos desvios. Os desvios são percebidos claramente nas empresas Adolpho e Viver, nos anos de 2012 e 2016, respectivamente.

Em 2012, a empresa Adolpho, obteve um índice de Giro de Ativo de 1,79, o mais alto dos anos calculados. A companhia ainda apresentou, de 2011 até 2014, índices acima de 1. Um dos possíveis motivos para o aumento do Giro do Ativo em 2012, é que a Receita Líquida aumentou 73\% de 2011 para 2012, e o Ativo Total teve um aumento de apenas $18 \%$.

Outro resultado que diverge dos demais, é o Índice de Giro do Ativo da empresa Viver em 2016, que apresentou o único índice negativo, de $-0,02$. O cenário macroeconômico que desde 2012 vêm desafiando a expansão e geração de caixa do setor, pode ter acarretado nesse resultado, visto que, em consequência desta situação, desde 2014 a empresa não lança novos empreendimentos.

Nessa mesma perspectiva, ao se analisar a média de Giro do Ativo por empresas, as empresas que mais se destacam são as mesmas que se destacaram anteriormente por terem resultados extremos, como mostra a Figura 3: 
Figura 3 - Giro do Ativo médio por empresa

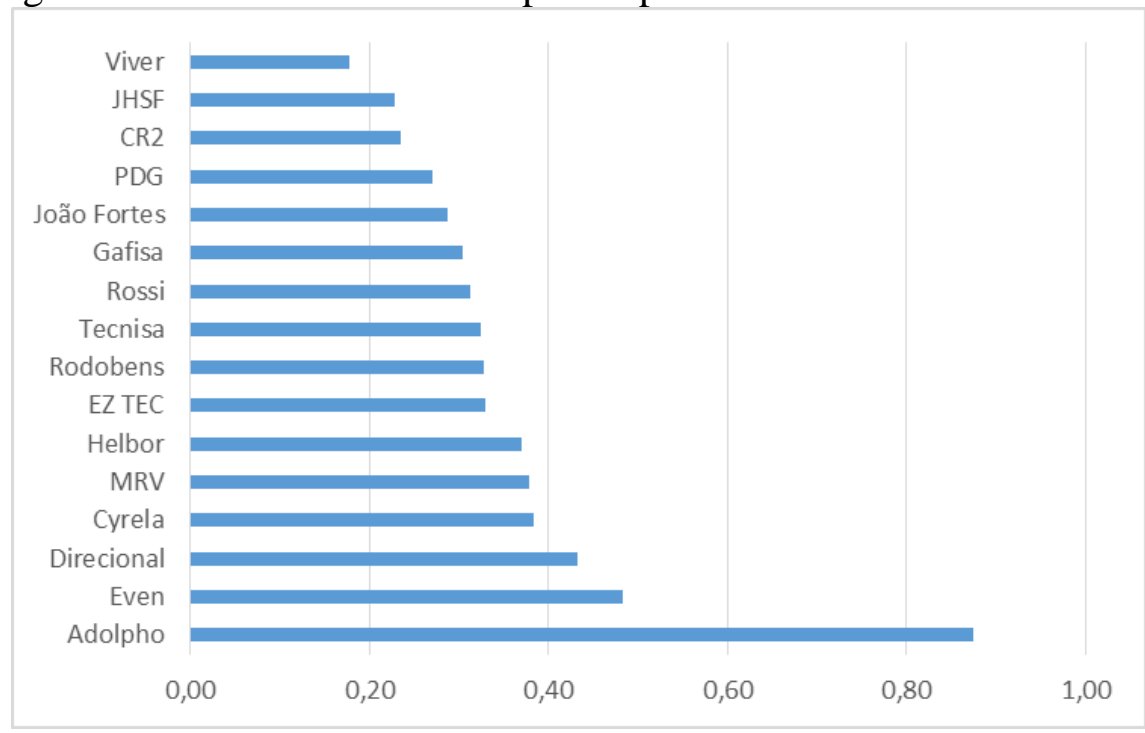

Fonte: elaboradora pelos autores

A empresa Viver, que anteriormente apresentou o menor índice dos anos pesquisados, também apresentou a menor média dos últimos dez anos, de 0,18 . Isso pode ser consequência da estratégia expansionista adotada em 2007 que se mostrou incompatível com a posterior deterioração do mercado, levando a empresa a entrar em Recuperação Judicial em 09 de novembro de 2016.

Por outro lado, a empresa Adolpho teve a maior média calculada, de 0,87. Apesar do baixo índice de Liquidez Seca apresentado em 2009 e 2010, com sua aquisição pelo Grupo LDI em 2008, ganhou robustez em relação a sua operação. Dessa forma, aumentando seus índices de Giro do Ativo nos anos subsequentes, levando à maior média do período.

No que diz respeito ao Giro do Ativo médio anual, os índices atingem seu ponto mais baixo em 2016 com 0,20 e seu ápice de 0,45 em 2010, apresentando valores muito próximos entre os índices calculados. Tal informação pode ser visualizada na Figura 4. 
Figura 4 - Giro do Ativo médio anual

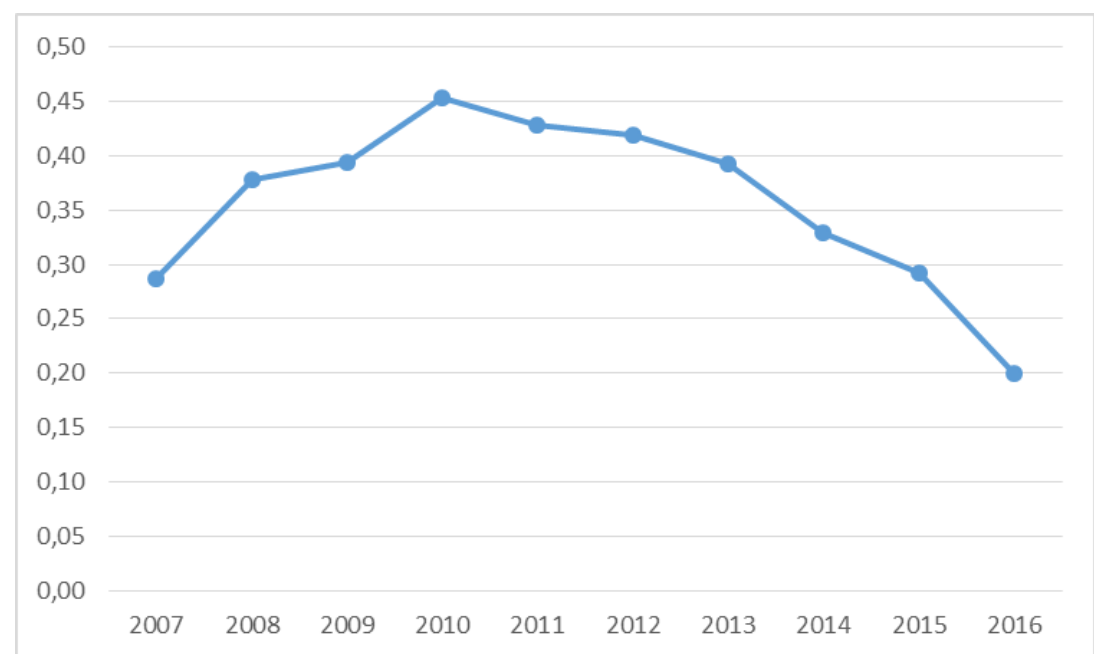

Fonte: elaborado pelos autores

Segundo Nogueira (2010), o desemprego chegou à 5,7\% em 2010, dando confiança as pessoas a demandarem bens que necessitam de crédito a mais longo prazo, como casas e carros. Juntamente com isso, a oferta de crédito era bem expressiva no Brasil, principalmente o crédito imobiliário. Possivelmente esses fatores contribuíram para o aumento da Receita Líquida, consequentemente aumentando o Giro do Ativo médio em 2010.

Em 2016, conforme Valor Econômico (2017), ocorreu um encolhimento da economia brasileira na ordem de $4,34 \%$, que pode ter contribuído para que o Giro Ativo médio de 2016, tenha sido o mais baixo dentre os anos calculados. Além disso é considerada a pior recessão já vivida pela economia brasileira, com uma contração de $8,1 \%$ nos últimos dois anos, como também pode ser acompanhado pela Figura 4.

\subsubsection{Rentabilidade do Ativo}

Para Marion (2009), o Ativo significa investimentos realizados pela empresa com a finalidade de obter receita, e consequentemente, lucro. Dessa forma, é possível obter a Taxa de Retorno sobre Investimentos, que representa o poder de ganho da empresa, ou seja, quanto ela ganhou por real investido. Em razão disso, a autora selecionou a Rentabilidade do Ativo com a finalidade de analisar a geração de resultados das companhias escolhidas.

Nessa mesma perspectiva, Iudícibus (2010), considera a Rentabilidade do Ativo como um dos quocientes individuais mais importantes da Análise de Balanços. Para encontrá-lo, utilizou-se a fórmula "Lucro Líquido / Ativo Total". 
Quadro 8 - Índices de Rentabilidade do Ativo Calculados

\begin{tabular}{|c|c|c|c|c|c|c|c|c|c|c|c|}
\hline & $\mathbf{2 0 0 7}$ & $\mathbf{2 0 0 8}$ & $\mathbf{2 0 0 9}$ & $\mathbf{2 0 1 0}$ & $\mathbf{2 0 1 1}$ & $\mathbf{2 0 1 2}$ & $\mathbf{2 0 1 3}$ & $\mathbf{2 0 1 4}$ & $\mathbf{2 0 1 5}$ & $\mathbf{2 0 1 6}$ & Média \\
\hline Adolpho & $-0,23$ & $-0,57$ & $-0,05$ & $-0,38$ & $-0,46$ & 0,17 & 0,54 & 0,19 & 0,27 & 0,10 & $-\mathbf{0 , 0 4}$ \\
\hline CR2 & 0,01 & 0,07 & 0,02 & 0,06 & 0,02 & $-0,03$ & $-0,02$ & $-0,09$ & $-0,12$ & $-0,22$ & $-\mathbf{0 , 0 3}$ \\
\hline Cyrela & 0,08 & 0,04 & 0,07 & 0,06 & 0,04 & 0,06 & 0,06 & 0,06 & 0,05 & 0,02 & $\mathbf{0 , 0 5}$ \\
\hline Direcional & 0,10 & 0,11 & 0,07 & 0,11 & 0,07 & 0,08 & 0,07 & 0,06 & 0,04 & 0,00 & $\mathbf{0 , 0 7}$ \\
\hline Even & 0,00 & 0,03 & 0,06 & 0,08 & 0,06 & 0,08 & 0,07 & 0,06 & 0,03 & 0,01 & $\mathbf{0 , 0 5}$ \\
\hline EZ TEC & 0,05 & 0,11 & 0,14 & 0,18 & 0,19 & 0,17 & 0,21 & 0,14 & 0,14 & 0,07 & $\mathbf{0 , 1 4}$ \\
\hline Gafisa & 0,03 & 0,04 & 0,02 & 0,03 & $-0,10$ & $-0,01$ & 0,11 & $-0,01$ & 0,01 & $-0,22$ & $-\mathbf{0 , 0 1}$ \\
\hline Helbor & 0,00 & 0,05 & 0,07 & 0,09 & 0,07 & 0,07 & 0,06 & 0,04 & 0,01 & $-0,02$ & $\mathbf{0 , 0 4}$ \\
\hline JHSF & 0,04 & 0,10 & 0,09 & 0,10 & 0,09 & 0,07 & 0,06 & 0,01 & 0,02 & $-0,05$ & $\mathbf{0 , 0 5}$ \\
\hline João Fortes & 0,00 & 0,01 & 0,10 & 0,07 & 0,04 & 0,01 & 0,02 & $-0,08$ & $-0,09$ & $-0,17$ & $-\mathbf{0 , 0 1}$ \\
\hline MRV & 0,01 & 0,09 & 0,09 & 0,10 & 0,09 & 0,06 & 0,04 & 0,07 & 0,05 & 0,05 & $\mathbf{0 , 0 6}$ \\
\hline PDG & 0,03 & 0,06 & 0,06 & 0,05 & 0,04 & $-0,13$ & $-0,01$ & $-0,03$ & $-0,26$ & $-1,17$ & $-\mathbf{0 , 1 4}$ \\
\hline Rodobens & 0,04 & 0,08 & 0,02 & 0,03 & 0,02 & 0,06 & 0,06 & 0,04 & 0,01 & $-0,05$ & $\mathbf{0 , 0 3}$ \\
\hline Rossi & 0,04 & 0,04 & 0,00 & 0,04 & 0,01 & $-0,02$ & 0,01 & $-0,09$ & $-0,10$ & $-0,11$ & $-\mathbf{0 , 0 2}$ \\
\hline Tecnisa & 0,03 & 0,05 & 0,05 & 0,06 & 0,04 & $-0,04$ & 0,06 & 0,04 & 0,08 & 0,15 & $\mathbf{0 , 0 5}$ \\
\hline Viver & $-0,04$ & $-0,04$ & 0,01 & 0,03 & $-0,04$ & $-0,19$ & $-0,14$ & $-0,15$ & $-0,20$ & $-0,35$ & $-\mathbf{0 , 1 1}$ \\
\hline Média & $\mathbf{0 , 0 1}$ & $\mathbf{0 , 0 2}$ & $\mathbf{0 , 0 5}$ & $\mathbf{0 , 0 4}$ & $\mathbf{0 , 0 1}$ & $\mathbf{0 , 0 2}$ & $\mathbf{0 , 0 7}$ & $\mathbf{0 , 0 2}$ & $\mathbf{0 , 0 0}$ & $\mathbf{- 0 , 1 2}$ & $\mathbf{0 , 0 1}$ \\
\hline
\end{tabular}

Fonte: elaborado pelos autores

Obs.: resultados centesimais

No Quadro 8, é possível perceber que apesar da maioria dos valores serem próximos, alguns são discrepantes em relação à maioria. É o caso da Adolpho em 2013, que atingiu o índice de 0,54 , o maior das companhias calculadas. Isso se deve ao Lucro Líquido que em 2013 foi de $\mathrm{R} \$ 18,8$ milhões, 518\% maior em relação ao ano anterior.

A empresa Adolpho ainda se destaca por ter grandes variações nos anos analisados. De 2007 à 2011, teve os valores mais baixos calculados em relação às outras companhias, chegando à $-0,57$ em 2008. Isso ocorre pois em 2008, a companhia apresentou um Prejuízo de R \$ 18,6 milhões e um Ativo Total de 32,5 milhões.

Nos anos seguintes, apresentou índices cada vez maiores, de 2011 à 2013 evidenciou um aumento de $217 \%$. Já em 2014, seu índice de Rentabilidade do Ativo voltou a decrescer, ficando mais próximo aos resultados encontrados nas outras companhias.

Por outro lado, a empresa PDG se destaca por ter o menor índice calculado, de -1,17 em 2016. A companhia, até 2015, teve índices muito próximos ao das empresas restantes. Já em 2016, sua Rentabilidade do Ativo teve uma queda de 350\% em relação ao ano anterior.

Com referência à Rentabilidade do Ativo média por empresa, é possível perceber que os índices encontrados variam de $-0,14$ à 0,14 , conforme mostra a Figura 5: 
Figura 5 - Rentabilidade do Ativo média por empresa

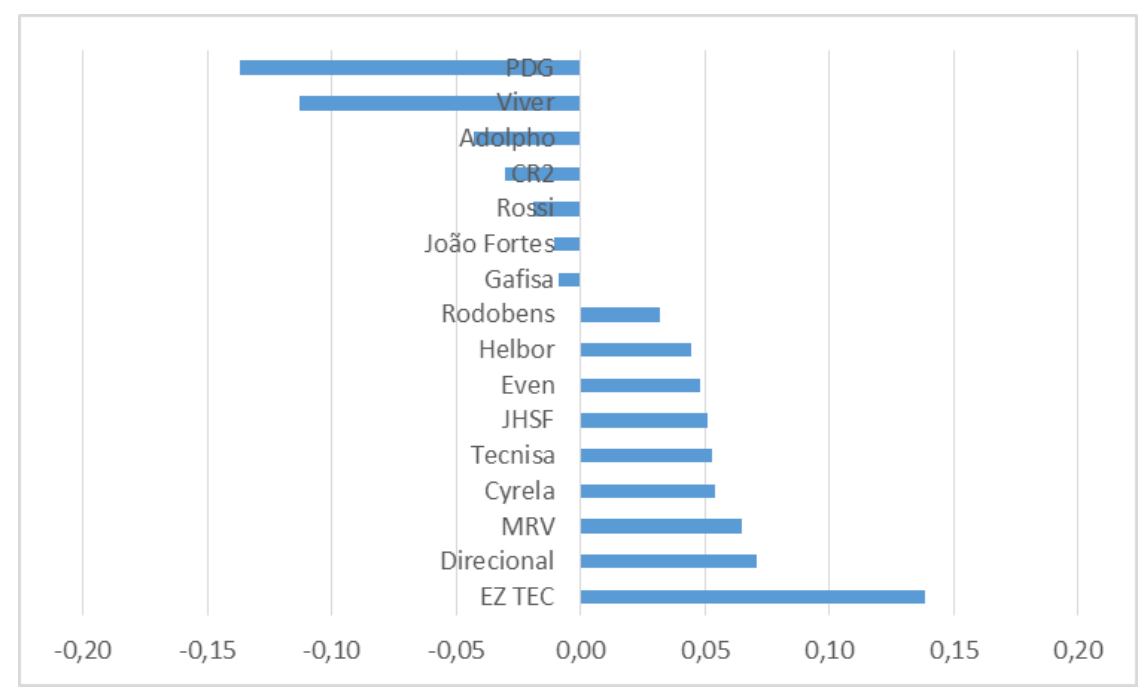

Fonte: elaborado pelos autores

Na Figura 5, é possível perceber que a empresa PDG, por causa de seu baixo índice em 2016, teve a menor média das empresas calculadas, de $-0,14$. Isso se deve às taxas de juros, desaceleração da atividade econômica e aumento do desemprego, distratos e inadimplência que se agravaram em 2016, levando a companhia a protocolar pedido de Recuperação Judicial em 22 de fevereiro de 2017.

Já a empresa EZ TEC, apresentou a maior média das empresas calculadas, de 0,14, sendo que em 2013 teve seu maior índice dos anos calculados, 0,21. A venda de uma das duas torres do projeto EZ Towers por R $\$ 564$ milhões em 2013 pode ter impactado nos resultados encontrados, além do lançamento de 9 empreendimentos residenciais e 3 comerciais no mesmo ano.

Ao se considerar a média anual da Rentabilidade do Ativo, existe grande diferença entre os valores encontrados, resultando numa linha de tendência irregular, como mostra a Figura 6:

Figura 6 - Rentabilidade do Ativo (média anual)

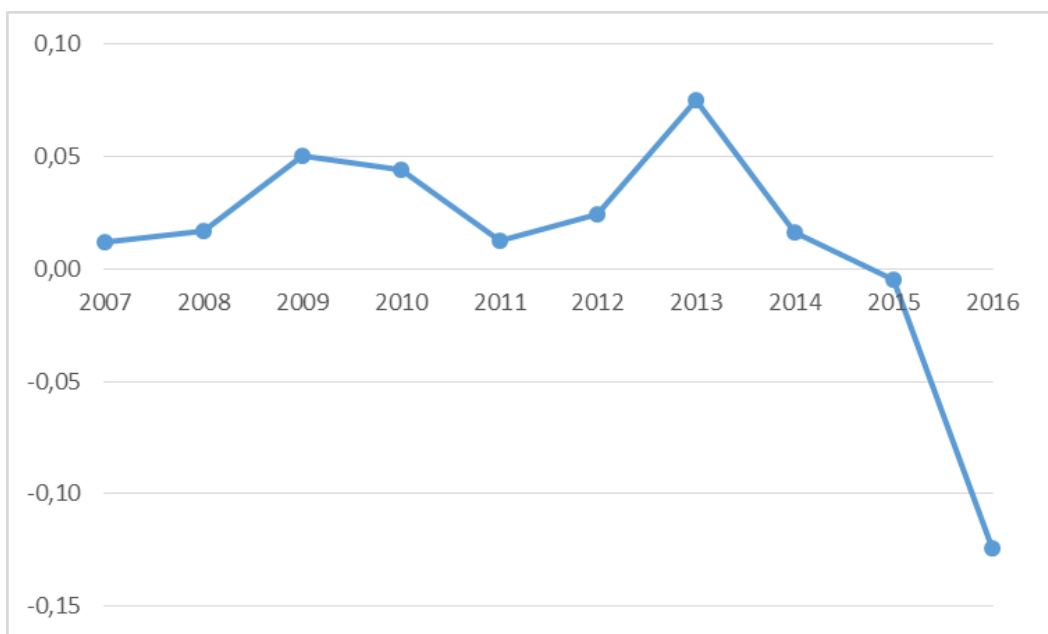

Fonte: elaborado pelos autores 
Percebe-se na Figura 6 que os valores encontrados são discrepantes, principalmente em 2013 e 2016, onde os índices calculados são de 0,07 e -0,12, respectivamente, um percentual de queda de $271 \%$ em apenas 3 anos.

Segundo Estadão (2014), em 2013 o Brasil apresentou o terceiro maior crescimento econômico do mundo, perdendo apenas para China e Coreia do Sul. Apesar desse resultado ter sido impulsionado pela agropecuária e também pela demanda de investimentos, é possível que tenha influenciado nos resultados encontrados de Rentabilidade do Ativo no setor de Construção Civil.

Por outro lado, em 2016, a média anual dos índices de Rentabilidade do Ativo foi a mais baixa calculada. Segundo Agência Brasil (2016), nesse ano houve uma contração na economia pelo segundo ano consecutivo, alta do dólar, inflação acima da projeção, queda no estoque de crédito, aumento da taxa de juros, etc. Esses fatores podem ter contribuído para diminuição do Lucro apurado no período pelas empresas avaliadas, gerando uma menor Rentabilidade do Ativo.

\subsubsection{Rentabilidade do Patrimônio Líquido}

Para fins de análise do retorno sobre o patrimônio líquido, foi escolhido o índice Rentabilidade do Patrimônio Líquido, o qual Iudícibus (2010) também considera de grande importância. Para encontrá-lo, utilizou-se a fórmula "Lucro Líquido / Patrimônio Líquido".

O mesmo autor ainda fundamenta que a importância do Quociente de Retorno sobre o Patrimônio Líquido (QRPL) reside em mostrar os resultados globais auferidos pela gerência na gestão de recursos próprios e de terceiros, em benefício dos acionistas. Sendo a principal tarefa da administração, maximizar o valor de mercado para o acionista e determinar dividendos compensadores. A longo prazo, o QRPL influencia também no valor de mercado das ações. Dessa maneira, o Quadro 9 apresenta os índices de Rentabilidade do Patrimônio Líquido obtidos no período analisado:

Quadro 9 - Rentabilidade do Patrimônio Líquido

\begin{tabular}{|c|c|c|c|c|c|c|c|c|c|c|c|}
\hline & $\mathbf{2 0 0 7}$ & $\mathbf{2 0 0 8}$ & $\mathbf{2 0 0 9}$ & $\mathbf{2 0 1 0}$ & $\mathbf{2 0 1 1}$ & $\mathbf{2 0 1 2}$ & $\mathbf{2 0 1 3}$ & $\mathbf{2 0 1 4}$ & $\mathbf{2 0 1 5}$ & $\mathbf{2 0 1 6}$ & Média \\
\hline Adolpho & 3,94 & 0,70 & 0,03 & 0,28 & 0,74 & $-0,52$ & 1,87 & 0,53 & 0,54 & 0,19 & $\mathbf{0 , 8 3}$ \\
\hline CR2 & 0,01 & 0,10 & 0,03 & 0,10 & 0,03 & $-0,06$ & $-0,02$ & $-0,11$ & $-0,13$ & $-0,25$ & $-\mathbf{0 , 0 3}$ \\
\hline Cyrela & 0,20 & 0,13 & 0,20 & 0,15 & 0,12 & 0,15 & 0,14 & 0,13 & 0,09 & 0,04 & $\mathbf{0 , 1 4}$ \\
\hline Direcional & 0,23 & 0,20 & 0,12 & 0,22 & 0,15 & 0,17 & 0,15 & 0,13 & 0,09 & 0,00 & $\mathbf{0 , 1 5}$ \\
\hline Even & 0,00 & 0,07 & 0,15 & 0,18 & 0,13 & 0,17 & 0,14 & 0,11 & 0,06 & 0,02 & $\mathbf{0 , 1 0}$ \\
\hline EZ TEC & 0,06 & 0,13 & 0,18 & 0,22 & 0,23 & 0,20 & 0,28 & 0,20 & 0,16 & 0,08 & $\mathbf{0 , 1 7}$ \\
\hline Gafisa & 0,06 & 0,11 & 0,06 & 0,08 & $-0,33$ & $-0,03$ & 0,27 & $-0,01$ & 0,02 & $-0,60$ & $-\mathbf{0 , 0 4}$ \\
\hline Helbor & 0,01 & 0,13 & 0,18 & 0,25 & 0,19 & 0,19 & 0,18 & 0,12 & 0,04 & $-0,06$ & $\mathbf{0 , 1 2}$ \\
\hline JHSF & 0,07 & 0,18 & 0,17 & 0,20 & 0,19 & 0,15 & 0,14 & 0,02 & 0,04 & $-0,11$ & $\mathbf{0 , 1 0}$ \\
\hline João Fortes & $-0,02$ & 0,03 & 0,25 & 0,27 & 0,16 & 0,04 & 0,05 & $-0,30$ & $-0,29$ & $-0,90$ & $-\mathbf{0 , 0 7}$ \\
\hline MRV & 0,02 & 0,15 & 0,15 & 0,22 & 0,22 & 0,14 & 0,10 & 0,16 & 0,12 & 0,11 & $\mathbf{0 , 1 4}$ \\
\hline PDG & 0,05 & 0,11 & 0,12 & 0,13 & 0,10 & $-0,40$ & $-0,03$ & $-0,09$ & $-1,19$ & 1,59 & $\mathbf{0 , 0 4}$ \\
\hline Rodobens & 0,06 & 0,14 & 0,04 & 0,11 & 0,07 & 0,14 & 0,14 & 0,08 & 0,01 & $-0,10$ & $\mathbf{0 , 0 7}$ \\
\hline Rossi & 0,07 & 0,10 & 0,01 & 0,09 & 0,04 & $-0,08$ & 0,02 & $-0,33$ & $-0,43$ & $-0,72$ & $-\mathbf{0 , 1 2}$ \\
\hline Tecnisa & 0,04 & 0,09 & 0,11 & 0,17 & 0,10 & $-0,12$ & 0,18 & 0,12 & 0,17 & 0,32 & $\mathbf{0 , 1 2}$ \\
\hline Viver & $-0,08$ & $-0,12$ & 0,02 & 0,06 & $-0,11$ & $-0,79$ & $-0,89$ & $-2,87$ & 1,42 & 0,68 & $-\mathbf{0 , 2 7}$ \\
\hline Média & $\mathbf{4 , 7 4}$ & $\mathbf{2 , 2 4}$ & $\mathbf{1 , 8 1}$ & $\mathbf{2 , 7 3}$ & $\mathbf{2 , 0 4}$ & $-\mathbf{0 , 6 3}$ & $\mathbf{2 , 7 2}$ & $\mathbf{- 2 , 1 0}$ & $\mathbf{0 , 7 1}$ & $\mathbf{0 , 2 7}$ & $\mathbf{1 , 4 5}$ \\
\hline
\end{tabular}

Fonte: elaborado pelos autores 
No Quadro 9, é possível perceber que a empresa Adolpho em 2007 teve a maior Rentabilidade do Patrimônio Líquido de todo o período em relação às outras empresas, de 3,94. Isso se deve, pois, a companhia apresentou um Prejuízo Líquido de R \$ 12,2 milhões e um Patrimônio Líquido negativo de R \$ 3,1 milhões, resultando num resultado matemático positivo.

Segundo Iudícibus (2017), em casos de prejuízos vultosos ou sucessivos, pode ocorrer situações em que o Patrimônio Líquido fica negativo, ou seja, o Capital Social não é o suficiente para cobrir todas as obrigações da empresa. Nessa situação, pode ser que a empresa esteja em processo de falência e liquidação de suas atividades. Portanto, para fins de análise contábil, as empresas em que ocorrem essa situação, ou seja, Adolpho de 2007 a 2011, PDG em 2016 e Viver em 2015 e 2016, serão excluídas da análise de Rentabilidade do Patrimônio Líquido que não correspondem à realidade. Diante disso, o Quadro 10 apresenta os cálculos de Rentabilidade do Patrimônio Líquido excluindo estas três empresas.

Quadro 10 - Rentabilidade do Patrimônio Líquido

\begin{tabular}{|c|c|c|c|c|c|c|c|c|c|c|c|}
\hline & $\mathbf{2 0 0 7}$ & $\mathbf{2 0 0 8}$ & $\mathbf{2 0 0 9}$ & $\mathbf{2 0 1 0}$ & $\mathbf{2 0 1 1}$ & $\mathbf{2 0 1 2}$ & $\mathbf{2 0 1 3}$ & $\mathbf{2 0 1 4}$ & $\mathbf{2 0 1 5}$ & $\mathbf{2 0 1 6}$ & Média \\
\hline CR2 & 0,01 & 0,10 & 0,03 & 0,10 & 0,03 & $-0,06$ & $-0,02$ & $-0,11$ & $-0,13$ & $-0,25$ & $-\mathbf{0 , 0 3}$ \\
\hline Cyrela & 0,20 & 0,13 & 0,20 & 0,15 & 0,12 & 0,15 & 0,14 & 0,13 & 0,09 & 0,04 & $\mathbf{0 , 1 4}$ \\
\hline Direcional & 0,23 & 0,20 & 0,12 & 0,22 & 0,15 & 0,17 & 0,15 & 0,13 & 0,09 & 0,00 & $\mathbf{0 , 1 5}$ \\
\hline Even & 0,00 & 0,07 & 0,15 & 0,18 & 0,13 & 0,17 & 0,14 & 0,11 & 0,06 & 0,02 & $\mathbf{0 , 1 0}$ \\
\hline EZ TEC & 0,06 & 0,13 & 0,18 & 0,22 & 0,23 & 0,20 & 0,28 & 0,20 & 0,16 & 0,08 & $\mathbf{0 , 1 7}$ \\
\hline Gafisa & 0,06 & 0,11 & 0,06 & 0,08 & $-0,33$ & $-0,03$ & 0,27 & $-0,01$ & 0,02 & $-0,60$ & $-\mathbf{0 , 0 4}$ \\
\hline Helbor & 0,01 & 0,13 & 0,18 & 0,25 & 0,19 & 0,19 & 0,18 & 0,12 & 0,04 & $-0,06$ & $\mathbf{0 , 1 2}$ \\
\hline JHSF & 0,07 & 0,18 & 0,17 & 0,20 & 0,19 & 0,15 & 0,14 & 0,02 & 0,04 & $-0,11$ & $\mathbf{0 , 1 0}$ \\
\hline João Fortes & $-0,02$ & 0,03 & 0,25 & 0,27 & 0,16 & 0,04 & 0,05 & $-0,30$ & $-0,29$ & $-0,90$ & $-\mathbf{0 , 0 7}$ \\
\hline MRV & 0,02 & 0,15 & 0,15 & 0,22 & 0,22 & 0,14 & 0,10 & 0,16 & 0,12 & 0,11 & $\mathbf{0 , 1 4}$ \\
\hline Rodobens & 0,06 & 0,14 & 0,04 & 0,11 & 0,07 & 0,14 & 0,14 & 0,08 & 0,01 & $-0,10$ & $\mathbf{0 , 0 7}$ \\
\hline Rossi & 0,07 & 0,10 & 0,01 & 0,09 & 0,04 & $-0,08$ & 0,02 & $-0,33$ & $-0,43$ & $-0,72$ & $-\mathbf{0 , 1 2}$ \\
\hline Tecnisa & 0,04 & 0,09 & 0,11 & 0,17 & 0,10 & $-0,12$ & 0,18 & 0,12 & 0,17 & 0,32 & $\mathbf{0 , 1 2}$ \\
\hline Média & $\mathbf{0 , 0 6}$ & $\mathbf{0 , 1 2}$ & $\mathbf{0 , 1 3}$ & $\mathbf{0 , 1 7}$ & $\mathbf{0 , 1 0}$ & $\mathbf{0 , 0 8}$ & $\mathbf{0 , 1 4}$ & $\mathbf{0 , 0 3}$ & $\mathbf{0 , 0 0}$ & $-\mathbf{0 , 1 7}$ & $\mathbf{0 , 0 7}$ \\
\hline
\end{tabular}

Fonte: elaborado pelos autores

Desconsiderando os resultados falsos positivos, pode-se perceber no Quadro 11 que a empresa EZ TEC apresentou um índice de Rentabilidade do Patrimônio Líquido de 0,28 em 2013, o maior no período avaliado. Em 2013, as vendas contratadas atingiram $\mathrm{R} \$ 1,61$ bilhão, volume $83 \%$ maior do que em 2012. Além de um Lucro Líquido de $\mathrm{R} \$ 588,7$ milhões, $74 \%$ maior do que o ano anterior.

Por outro lado, a empresa João Fortes apresentou a menor Rentabilidade do Patrimônio Líquido do período em comparação às outras empresas, 0,90 em 2016. Isso se deve à um Prejuízo Líquido de R \$ 457,7 milhões, 61\% maior se comparado ao ano anterior resultado da queda dos preços de imóveis e volume recorde de distratos no ano.

Ao se considerar a Rentabilidade do Patrimônio Líquido média por empresa, pode se perceber uma diferença de $242 \%$ entre a menor média e a maior, como demonstra a Figura 7: 
Figura 7 - Rentabilidade do Patrimônio Líquido por empresa

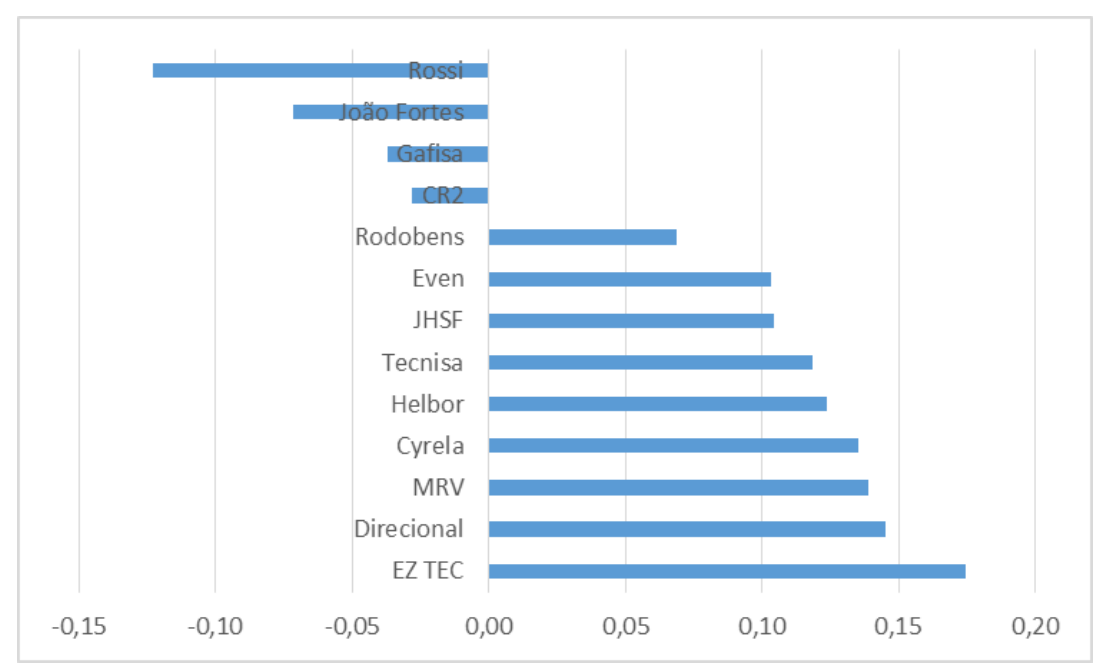

Fonte: elaborado pelos autores

É possível perceber na Figura 7 que a empresa EZ TEC apresentou a maior média de Rentabilidade do Patrimônio Líquido, 0,17. Isso se deve ao desenvolvimento bem-sucedido em novos mercados de atuação, como o lançamento do projeto corporativo EZ Towers, além de busca pela reaplicação de recursos oriundos na operação de anos anteriores em novas oportunidades.

Já a empresa Rossi obteve uma média de $(0,12)$ no período avaliado, a menor comparado às empresas calculadas. Seu menor índice de Rentabilidade do Patrimônio Líquido foi apresentado em 2016, (0,72), apesar de seu Lucro Líquido ter aumentado $4 \%$ em relação ao ano anterior. Isso é resultado da forte deterioração da economia que culminou numa redução de 3,6\% do PIB (Produto Interno Bruto).

Analisando-se a Rentabilidade do Patrimônio Líquido média por ano, percebese uma grande diferença entre a menor e a maior média calculadas, ou seja, uma diferença de 200\%. Considerando que em 2010 obteve-se a maior média de 0,17 e a menor -0,17, em 2016, como é possível ver na Figura 8: 
Figura 8 - Rentabilidade do Patrimônio Líquido (média anual)

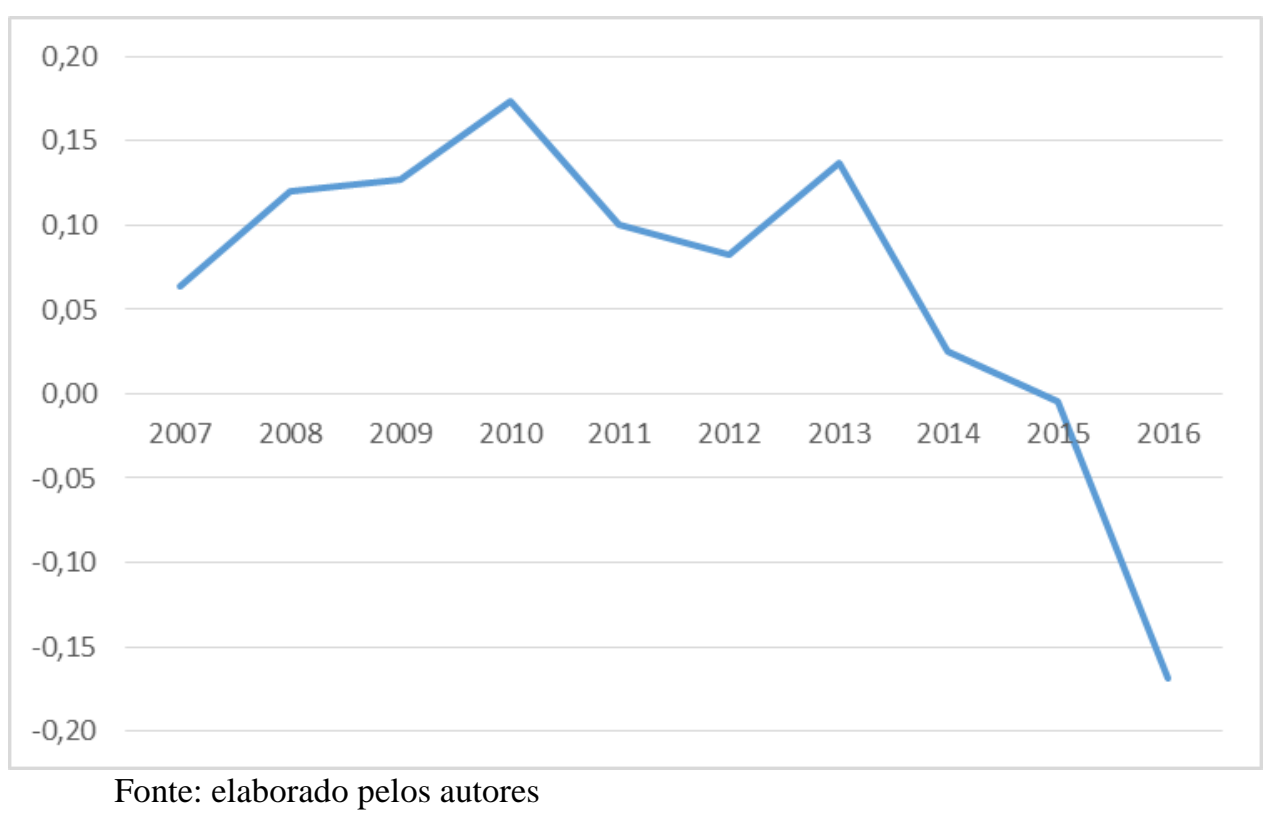

Na Figura 8, o ano de 2010 apresenta a maior média anual de Rentabilidade do Patrimônio Líquido, de 0,17. Segundo Lorenzi (2011), em 2010, a economia brasileira apresentou um crescimento de 7,5\%, superando o PIB apresentado em 1986, ano em que foi lançado o Plano Cruzado, refletindo o aumento no consumo das famílias, o que pode ter ocasionado no resultado encontrado no cálculo de médias da Rentabilidade do Patrimônio Líquido.

Já em 2016, houve a menor média anual, de -0,17. Conforme G1 (2016), nesse ano a produção teve queda acentuada, gerando desemprego e a inflação teve alta. Esses fatores podem ter gerado um aumento na inadimplência das empresas analisadas, ocasionando no resultado encontrado.

\subsubsection{Grau de Endividamento}

Segundo Assaf Neto (2015), quando empresas não possuem condições financeiras próprias para suprir a demanda de sua atividade, utiliza-se capital de terceiros. Em consequência disto, para analisar quanto do capital próprio aplicado na companhia está comprometido com dívidas, foi escolhido o índice que apresenta o Grau de Endividamento. Para encontra-lo, utilizou-se a fórmula "Passivo Total / Patrimônio Líquido".

O Quadro 11 evidencia os valores de Endividamento constatados nas empresas analisadas: 
Quadro 21 - Índice de Grau de Endividamento calculados

\begin{tabular}{|c|c|c|c|c|c|c|c|c|c|c|c|}
\hline & $\mathbf{2 0 0 7}$ & $\mathbf{2 0 0 8}$ & $\mathbf{2 0 0 9}$ & $\mathbf{2 0 1 0}$ & $\mathbf{2 0 1 1}$ & $\mathbf{2 0 1 2}$ & $\mathbf{2 0 1 3}$ & $\mathbf{2 0 1 4}$ & $\mathbf{2 0 1 5}$ & $\mathbf{2 0 1 6}$ & Média \\
\hline Adolpho & $-16,94$ & $-1,22$ & $-0,60$ & $-0,73$ & $-1,63$ & $-3,12$ & 3,44 & 2,80 & 2,05 & 2,07 & $-\mathbf{1 , 3 9}$ \\
\hline CR2 & 1,18 & 1,49 & 1,78 & 1,89 & 1,79 & 1,62 & 1,49 & 1,23 & 1,14 & 1,13 & $\mathbf{1 , 4 7}$ \\
\hline Cyrela & 2,53 & 3,56 & 2,57 & 2,57 & 2,77 & 2,42 & 2,32 & 2,11 & 1,91 & 1,76 & $\mathbf{2 , 4 5}$ \\
\hline Direcional & 2,41 & 1,81 & 1,61 & 2,03 & 1,99 & 2,10 & 2,14 & 2,28 & 2,19 & 2,34 & $\mathbf{2 , 0 9}$ \\
\hline Even & 1,78 & 2,16 & 2,47 & 2,17 & 2,11 & 2,06 & 2,07 & 2,02 & 2,08 & 2,07 & $\mathbf{2 , 1 0}$ \\
\hline EZ TEC & 1,22 & 1,16 & 1,23 & 1,24 & 1,25 & 1,23 & 1,35 & 1,41 & 1,22 & 1,24 & $\mathbf{1 , 2 5}$ \\
\hline Gafisa & 2,00 & 2,52 & 3,13 & 2,49 & 3,46 & 3,24 & 2,55 & 2,36 & 2,18 & 2,70 & $\mathbf{2 , 6 6}$ \\
\hline Helbor & 2,26 & 2,53 & 2,71 & 2,88 & 2,75 & 2,94 & 2,86 & 2,84 & 2,72 & 2,86 & $\mathbf{2 , 7 3}$ \\
\hline JHSF & 1,54 & 1,87 & 1,98 & 1,98 & 2,18 & 2,23 & 2,39 & 2,54 & 2,46 & 2,14 & $\mathbf{2 , 1 3}$ \\
\hline João Fortes & 4,78 & 2,40 & 2,50 & 3,62 & 4,28 & 3,67 & 3,40 & 3,68 & 3,13 & 5,20 & $\mathbf{3 , 6 7}$ \\
\hline MRV & 1,39 & 1,63 & 1,73 & 2,22 & 2,50 & 2,53 & 2,34 & 2,31 & 2,26 & 2,27 & $\mathbf{2 , 1 2}$ \\
\hline PDG & 1,90 & 1,97 & 2,07 & 2,58 & 2,64 & 3,03 & 3,15 & 3,15 & 4,60 & $-1,36$ & $\mathbf{2 , 3 7}$ \\
\hline Rodobens & 1,41 & 1,72 & 2,35 & 3,21 & 2,90 & 2,24 & 2,25 & 2,15 & 2,00 & 2,09 & $\mathbf{2 , 2 3}$ \\
\hline Rossi & 2,04 & 2,34 & 2,19 & 2,58 & 3,22 & 3,29 & 3,08 & 3,69 & 4,15 & 6,57 & $\mathbf{3 , 3 1}$ \\
\hline Tecnisa & 1,47 & 1,69 & 2,29 & 2,62 & 2,23 & 2,75 & 2,97 & 2,82 & 2,17 & 2,16 & $\mathbf{2 , 3 2}$ \\
\hline Viver & 2,01 & 2,70 & 2,44 & 2,25 & 2,99 & 4,15 & 6,28 & 18,79 & $-7,08$ & $-1,93$ & $\mathbf{3 , 2 6}$ \\
\hline Média & $\mathbf{0 , 8 1}$ & $\mathbf{1 , 9 0}$ & $\mathbf{2 , 0 3}$ & $\mathbf{2 , 2 2}$ & $\mathbf{2 , 3 4}$ & $\mathbf{2 , 2 7}$ & $\mathbf{2 , 7 6}$ & $\mathbf{3 , 5 1}$ & $\mathbf{1 , 8 2}$ & $\mathbf{2 , 0 8}$ & $\mathbf{2 , 1 7}$ \\
\hline
\end{tabular}

Fonte: elaborado pelos autores

No Quadro 11, é possível perceber que entre o menor e o maior índice, de 16,94 e 18,79, Adolpho em 2007 e Viver em 2014, respectivamente, existe uma diferença de $211 \%$. A empresa Adolpho apresentou o menor índice do período avaliado, devido ao seu Passivo Total de R \$ 52,6 milhões e seu Patrimônio Líquido negativo de R \$ 3,1 milhões em 2007.

Devido ao Patrimônio Líquido negativo, o valor encontrado matematicamente não corresponde à realidade. Assim como ocorre de 2008 a 2012, e também nas empresas PDG em 2016 e Viver em 2015 e 2016. Portanto, essas empresas foram retiradas da amostra para que não desvirtuem as análises. O Quadro 12 apresenta os valores encontrados nas empresas analisadas:

Quadro 12 - Índice de Grau de Endividamento calculados

\begin{tabular}{|c|c|c|c|c|c|c|c|c|c|c|c|}
\hline & $\mathbf{2 0 0 7}$ & $\mathbf{2 0 0 8}$ & $\mathbf{2 0 0 9}$ & $\mathbf{2 0 1 0}$ & $\mathbf{2 0 1 1}$ & $\mathbf{2 0 1 2}$ & $\mathbf{2 0 1 3}$ & $\mathbf{2 0 1 4}$ & $\mathbf{2 0 1 5}$ & $\mathbf{2 0 1 6}$ & Média \\
\hline CR2 & 1,18 & 1,49 & 1,78 & 1,89 & 1,79 & 1,62 & 1,49 & 1,23 & 1,14 & 1,13 & $\mathbf{1 , 4 7}$ \\
\hline Cyrela & 2,53 & 3,56 & 2,57 & 2,57 & 2,77 & 2,42 & 2,32 & 2,11 & 1,91 & 1,76 & $\mathbf{2 , 4 5}$ \\
\hline Direcional & 2,41 & 1,81 & 1,61 & 2,03 & 1,99 & 2,10 & 2,14 & 2,28 & 2,19 & 2,34 & $\mathbf{2 , 0 9}$ \\
\hline Even & 1,78 & 2,16 & 2,47 & 2,17 & 2,11 & 2,06 & 2,07 & 2,02 & 2,08 & 2,07 & $\mathbf{2 , 1 0}$ \\
\hline EZ TEC & 1,22 & 1,16 & 1,23 & 1,24 & 1,25 & 1,23 & 1,35 & 1,41 & 1,22 & 1,24 & $\mathbf{1 , 2 5}$ \\
\hline Gafisa & 2,00 & 2,52 & 3,13 & 2,49 & 3,46 & 3,24 & 2,55 & 2,36 & 2,18 & 2,70 & $\mathbf{2 , 6 6}$ \\
\hline Helbor & 2,26 & 2,53 & 2,71 & 2,88 & 2,75 & 2,94 & 2,86 & 2,84 & 2,72 & 2,86 & $\mathbf{2 , 7 3}$ \\
\hline JHSF & 1,54 & 1,87 & 1,98 & 1,98 & 2,18 & 2,23 & 2,39 & 2,54 & 2,46 & 2,14 & $\mathbf{2 , 1 3}$ \\
\hline João Fortes & 4,78 & 2,40 & 2,50 & 3,62 & 4,28 & 3,67 & 3,40 & 3,68 & 3,13 & 5,20 & $\mathbf{3 , 6 7}$ \\
\hline MRV & 1,39 & 1,63 & 1,73 & 2,22 & 2,50 & 2,53 & 2,34 & 2,31 & 2,26 & 2,27 & $\mathbf{2 , 1 2}$ \\
\hline Rodobens & 1,41 & 1,72 & 2,35 & 3,21 & 2,90 & 2,24 & 2,25 & 2,15 & 2,00 & 2,09 & $\mathbf{2 , 2 3}$ \\
\hline Rossi & 2,04 & 2,34 & 2,19 & 2,58 & 3,22 & 3,29 & 3,08 & 3,69 & 4,15 & 6,57 & $\mathbf{3 , 3 1}$ \\
\hline Tecnisa & 1,47 & 1,69 & 2,29 & 2,62 & 2,23 & 2,75 & 2,97 & 2,82 & 2,17 & 2,16 & $\mathbf{2 , 3 2}$ \\
\hline Média & $\mathbf{2 , 0 0}$ & $\mathbf{2 , 0 7}$ & $\mathbf{2 , 2 0}$ & $\mathbf{2 , 4 2}$ & $\mathbf{2 , 5 7}$ & $\mathbf{2 , 4 8}$ & $\mathbf{2 , 4 0}$ & $\mathbf{2 , 4 2}$ & $\mathbf{2 , 2 8}$ & $\mathbf{2 , 6 6}$ & $\mathbf{2 , 3 5}$ \\
\hline
\end{tabular}

Fonte: Elaborado pelos autores

É possível perceber no Quadro 12 que a empresa CR2 apresentou um Índice de Grau de Endividamento de 1,13 em 2016. O que significa que, apesar de ter a menor dependência de capital de terceiros, a empresa tomou de empréstimos $\mathrm{R} \$ 1,13$ para cada 
$\mathrm{R} \$ 1,00$ de capital próprio investido. Houve uma queda de $21 \%$ no Passivo Total em comparação ao ano anterior, possível resultado de uma queda de $37 \%$ nas despesas gerais e administrativas que pode ter ocasionado no resultado encontrado.

No mesmo ano, a empresa Rossi apresentou o maior índice do período, de 6,57, um aumento de 58\% em relação ao ano anterior, apesar de o Passivo Total ter sofrido uma queda de $8 \%$. Isso aconteceu, pois, a empresa apresentou um Prejuízo de $\mathrm{R}$ \$ R \$ 528,4 milhões em 2016, que somando com prejuízos acumulados de outro ano, resultou numa diminuição da Patrimônio Líquido de $42 \%$.

Considerando-se o Grau de Endividamento por empresa, é possível perceber uma diferença de $193 \%$ entre a maior e menor média, que são apresentadas pelas empresas João Fortes e EZ TEC respectivamente, como evidencia a Figura 9:

Figura 9 - Grau de Endividamento por empresa

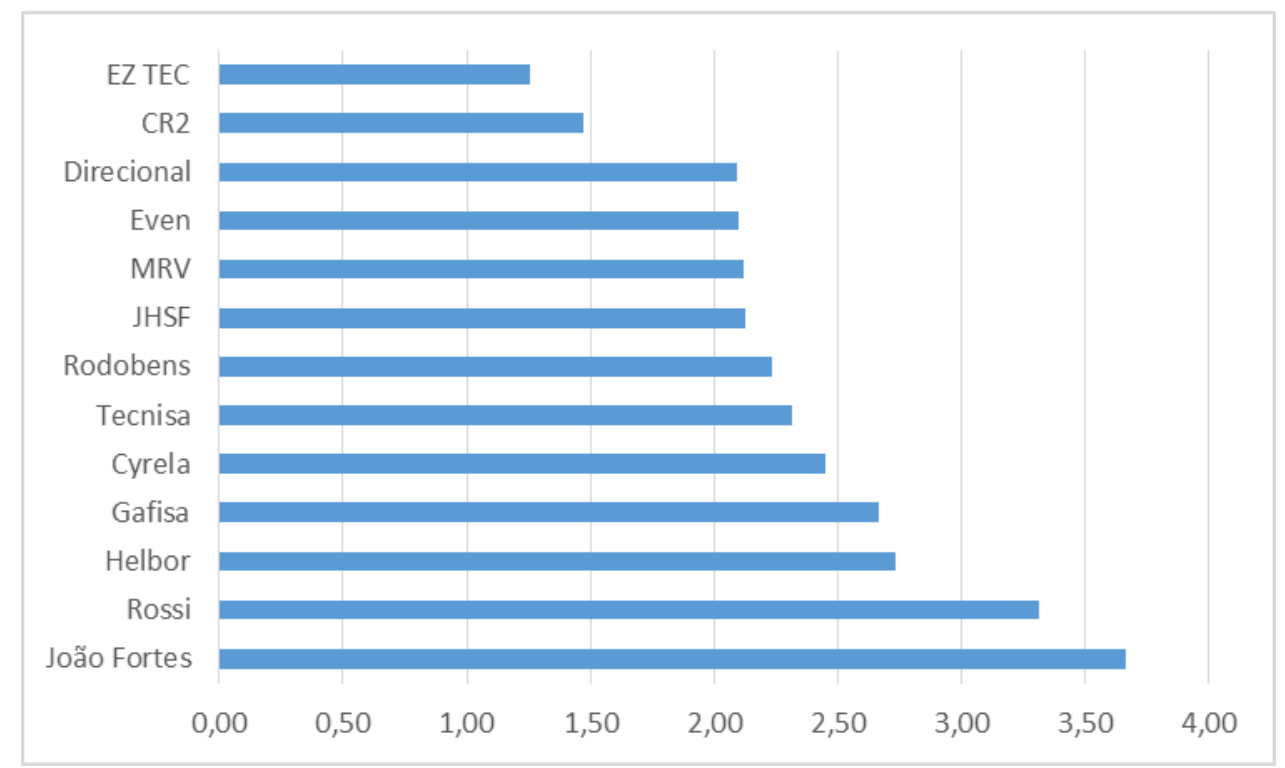

Fonte: elaborado pelos autores

A empresa EZ TEC apresentou o menor Grau de Endividamento médio das empresas analisadas. Durante todo o período calculado, a empresa manteve seus índices entre 1,16 e 1,41 . Um dos motivos que podem ter influenciado no resultado encontrado é a empresa reduziu seus custos e despesas quando houve diminuição de Receitas, dessa forma, honrou seus compromissos sem comprometer a geração de caixa.

Já a empresa João Fortes apresentou o maior índice de Grau de Endividamento no período avaliado, de 3,67. Ou seja, para cada $\mathrm{R} \$ 1,00$ de capital próprio investido, a companhia tomou $\mathrm{R} \$ 3,67$ de empréstimos em média nos últimos dez anos. No ano de 2016 a empresa obteve seu maior Grau de Endividamento, de 5,20. A deterioração do ambiente de negócios, alta de juros, queda na atividade econômica e redução no acesso aos créditos imobiliários são fatores que contribuíram para a queda nas vendas e aumento de distratos, possivelmente levando ao resultado encontrado.

Por outro lado, ao analisarmos a média de todas as empresas por ano, percebese que 2016 não foi o maior encontrado, diferente do ocorrido com a empresa João Fortes, como é possível perceber na Figura 10: 
Figura 10 - Grau de Endividamento (média anual)

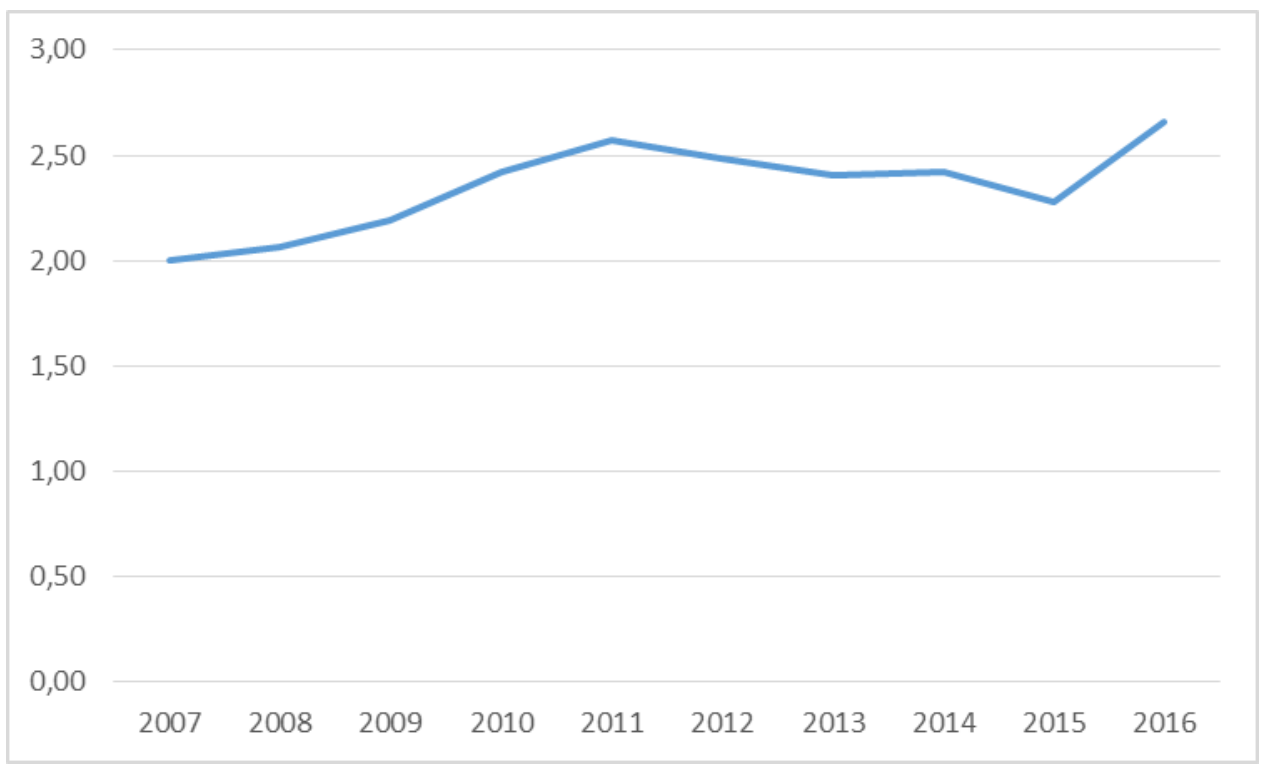

Fonte: elaborado pelos autores

Na figura 10 é possível perceber que a menor média anual de Grau de Endividamento encontrado é em 2007, onde o índice é de 2,00, o que significa em nesse ano, houve uma menor dependência de capital de terceiros. Farid e Chiarini (2008) afirmam que em 2007 houve recorde de investimentos estrangeiros no país e a economia brasileira cresceu $5,4 \%$. Tais fatores podem ter contribuído para que as empresas melhorassem sua operação e com isso, honrar seus passivos sem a utilização de capital de terceiros.

Já em 2016, houve a maior média de Grau Endividamento, de 2,66. O site IG (2016) afirma que a construção vem sentindo o impacto da redução da demanda visto que a abertura de novos empreendimentos, compra de insumos e número de empregados apresentaram queda em 2016, reflexo da queda de consumo no setor. Esses fatores podem ter influenciado na necessidade de obter capital de terceiros para manter a operação das empresas analisadas.

\subsection{Considerações finais}

Com o presente estudo, foi possível perceber os períodos de menor e maior dificuldade para as empresas pesquisadas, além da situação econômica e financeira das empresas no período. No que diz respeito à análise por empresas, é possível perceber que os resultados dos índices se complementam se analisadas em sua globalidade.

Por exemplo, a empresa EZ TEC apresentou os maiores índices de Liquidez Seca, Rentabilidade do Ativo e Rentabilidade do Patrimônio Líquido em relação às 
outras empresas pesquisadas, bem como o menor Índice de Endividamento. Dessa forma, evidenciando que a empresa tem capacidade de pagamentos de suas dívidas no curto prazo, sua operação é rentável e a empresa tem baixa dependência de empréstimos de terceiros.

Nessa mesma perspectiva, a empresa João Fortes também apresentou resultados coerentes em sua totalidade que se destacaram em relação às outras empresas. A companhia evidenciou baixa capacidade de saldar as dívidas de curto prazo, baixo retorno de investimentos operacionais e aos acionistas e alta dependência de empréstimos de terceiros.

De uma forma geral, percebeu-se uma tendência de queda nos índices calculados, com exceção do Grau de Endividamento, que apresenta tendência de aumento. $\mathrm{O}$ que é perfeitamente compreensível pois sua interpretação é contrária ao restante dos índices. Para melhor compreensão, apresenta-se a Figura 11:

Figura 11 - Tendência da Média Anual dos índices Calculados

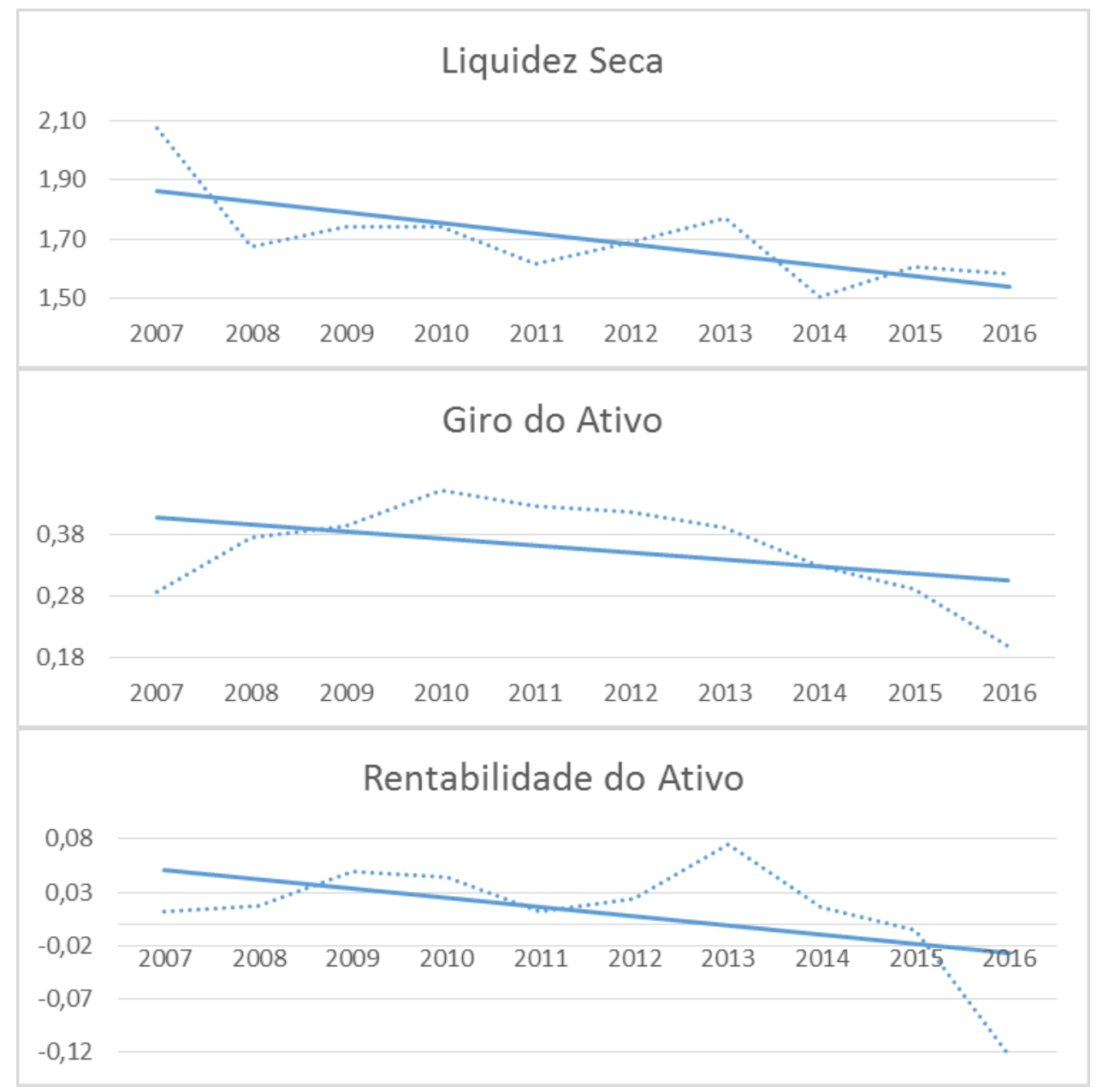




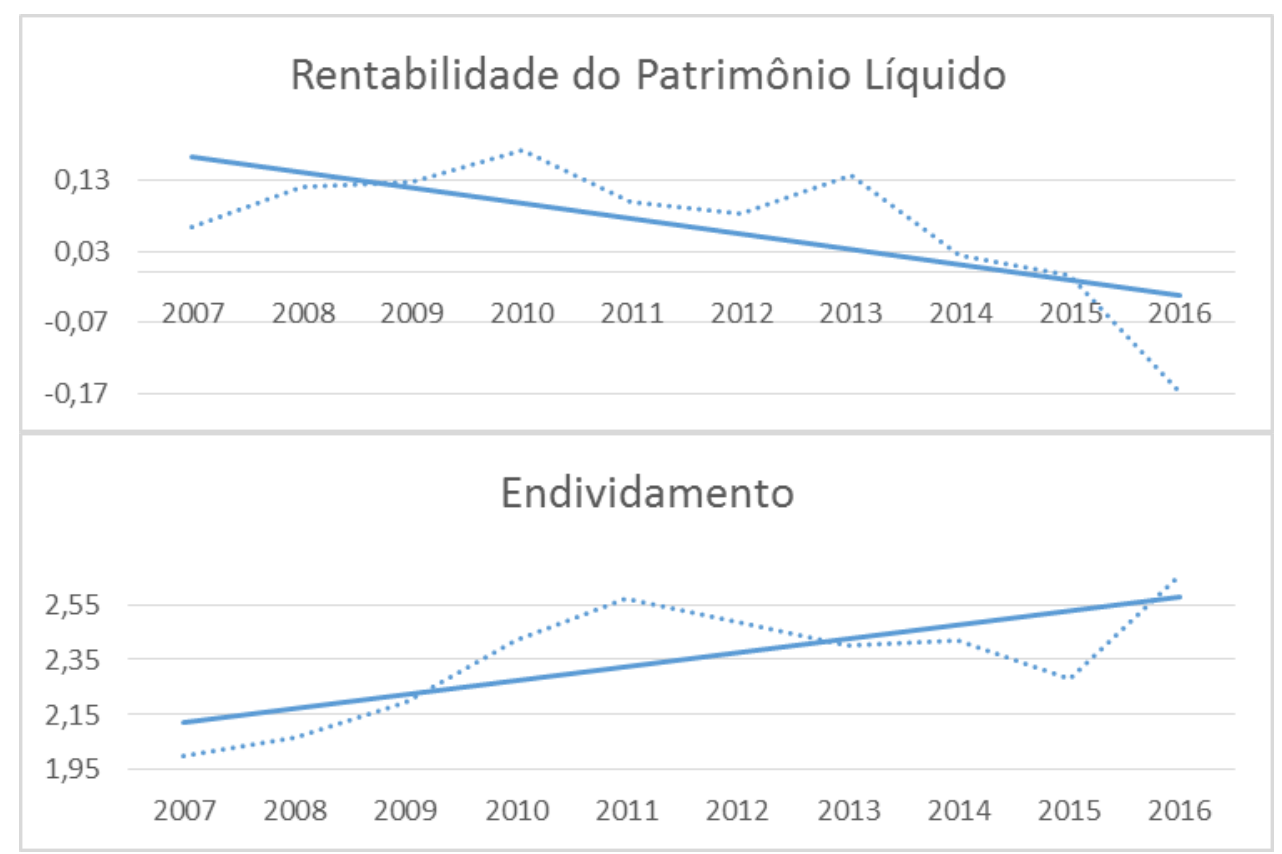

Fonte: Elaborado pelos autores

Obs: a linha contínua representa a tendência

Na Figura 11 é possível perceber que, com exceção do Grau de Endividamento, todos os índices sofrem uma queda em 2016. O Giro do Ativo, a Rentabilidade do Ativo e a Rentabilidade do Patrimônio apresentam seus menores índices no ano citado. Já a Liquidez Seca, apresenta seu menor índice em 2014, porém houve uma nova queda em 2016, ficando apenas 4,6\% acima do menor índice.

Nessa mesma perspectiva, o Grau de Endividamento em 2016 teve o maior índice apresentado, expondo maior necessidade de captar recursos de terceiros para manter a operação. Em razão disso, é possível perceber que o ano de 2016 foi um ano de recessão.

No que diz respeito à economia, é possível perceber os resultados financeiros das empresas em conformidade com as oscilações econômicas ocorridas no período, como apresenta a Figura 12:

Figura 12 - Tendência da Variação Percentual do PIB

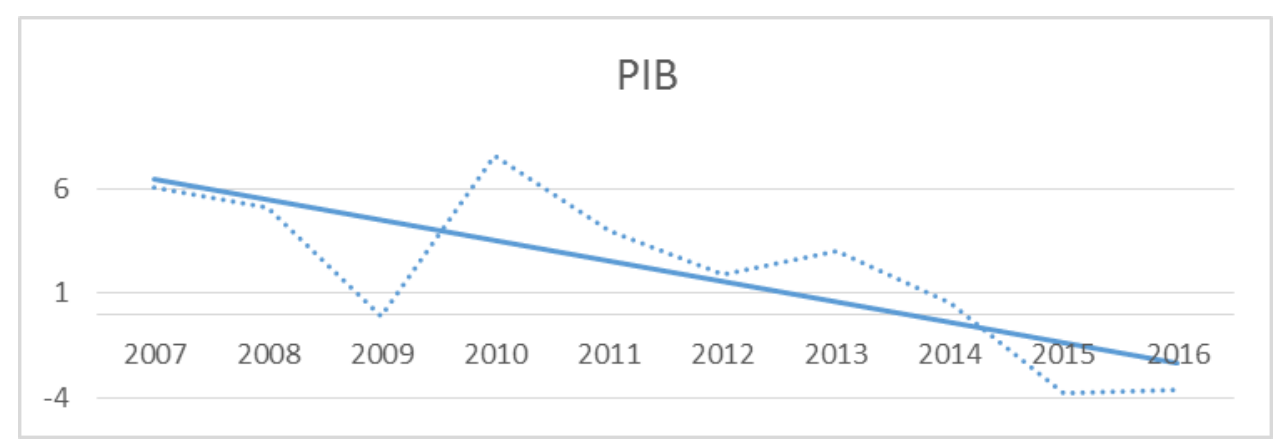

Fonte: elaborado pelos autores

Obs: a linha contínua representa a tendência 
A variação do PIB encontrada no período em relação aos resultados econômicos e financeiros das empresas é compreensível visto que para cálculo do PIB, as empresas do setor da Construção Civil também são incluídas.

Nessa mesma perspectiva, os resultados encontrados na análise dos índices também podem ser resultado de um desaquecimento na economia. Conforme Notícias Minuto a Minuto (2017), devido ao prolongamento da crise, o percentual de imóveis comerciais desocupados saltou de 3,56\% em 2010 para 17,47\% em 2016. O Brasil está passando pela pior recessão da história, com queda no PIB da Construção Civil de 6,5\% em 2015 e 5,2\% em 2016, provocando também grande volume de distratos.

Para 2017, segundo Zaremba (2017), após o difícil ano para o setor da Construção Civil em 2016, a previsão é de retomada nas vendas e nos lançamentos em 2017, dependendo do desdobramento das crises políticas e econômicas brasileiras. A autora acredita que a redução da taxa de juros, o baixo nível de desemprego e marcos regulatórios são fatores influenciadores na recuperação do setor, aumentando a confiança dos consumidores dispostos a investir em imóveis.

Nessa mesma perspectiva, G1 (2017) afirma que em 2017 o setor deve voltar a visualizar crescimento devido à retração de custos das obras, como materiais, equipamentos e serviços. Esse fator influenciou investidores do setor a traçar estratégias para aproveitar a melhora na situação econômica.

\section{Conclusão}

A análise das demonstrações contábeis através de índices tem como finalidade apontar informações econômicas e financeiras que sirvam de auxílio para tomada de decisões. Tomar decisões assertivas em períodos de recessão econômica ou não, se faz necessário para que a empresa melhore seus resultados. A aplicação de índices econômicos e financeiros é fundamental para conhecer a saúde da empresa.

O setor da Construção Civil tem grande importância na economia devido à quantidade de atividades envolvidas, como comércio de materiais e equipamentos, mão de obra, serviços de venda e aluguel, etc. Por essa razão, a pesquisa também buscou melhor compreensão da relação entre resultados econômicos e financeiros das empresas selecionadas e oscilações da economia brasileira.

Através da análise dos resultados econômicos e financeiros das empresas selecionadas, foi possível perceber indícios de quais foram os períodos de recessão e crescimento econômico. Situação em que, ao analisar a evolução da economia brasileira no período, o resultado corroborou com a hipótese supracitada.

Utilizando-se da análise dos índices, juntamente com comparação das Notas Explicativas e da situação econômica brasileira, foi possível alcançar o objetivo proposto. A pesquisa evidenciou que todas as empresas analisadas sofreram impactos no período, possivelmente causados pela oscilação da economia. Porém, provavelmente devido às estratégias adotadas por cada companhia, os resultados encontrados foram diferentes, ou seja, algumas empresas tiveram maior impacto no resultado quando comparadas com outras, do mesmo setor.

Acredita-se que as estratégias adotadas pelas companhias tenham influenciado no resultado, porém, devido à falta de informações sobre o tópico nas Notas Explicativas de algumas empresas analisadas, o estudo apresentou limitações. Outro fator limitante para aprofundamento da pesquisa com relação às Notas Explicativas, foi 
a reduzida quantidade de informações em itens que apresentaram grandes diferenças entre anos, dificultando o entendimento de justificativas para tais resultados.

Sugere-se que sejam feitos novos estudos que envolvam empresas do Setor de Construção que não foram incluídas no presente estudo. O objetivo dessa pesquisa seria verificar se houveram impactos da mesma proporção em empresas de variados portes, mas dentro do mesmo setor. Além de evidenciar a importância da análise das demonstrações contábeis em empresas de pequeno porte que não contam com especialistas em gestão.

Propõe-se também uma continuação do presente estudo aplicando em empresas do setor de consumo não cíclico, com a finalidade de avaliar se houve menor ou maior impacto nos períodos de recessão em comparação às empresas de consumo cíclico.

\section{Referências}

Agência Brasil. Confira os acontecimentos que marcaram a economia brasileira em 2016. 2016. Disponível em: <http://economia.ig.com.br/2016-12-20/fatos-marcanteseconomia-2016.html>. Acesso em: 15 abr. 2017.

AMORIM, Lucas. Construção Civil vive crise sem precedentes no Brasil. 2015.

Disponível em: <http://exame.abril.com.br/revista-exame/edicoes/109202/noticias/acrise-e-a-crise-da-construcao $>$. Acesso em: 01 set. 2016.

ANDERSEN, Spencer. A history os the past 40 years in Financial Crises. International Financing Review, Londres, Inglaterra, v. 2000, p.48-52, set. 2013.

ANDRADE, Maria Margarida de. Introdução à Metodologia do Trabalho

Científico: Elaboração de trabalhos na graduação. 10. ed. São Paulo: Atlas, 2010. 158 p.

ANTUNES, Maria Thereza Pompa et al. A adoção no Brasil das normas internacionais de contabilidade IFRS: o processo e seus impactos na qualidade da informação

contábil. Revista de Economia e Relações Internacionais, São Paulo, v. 10, n. 20, p.519, jan. 2012. Semestral. Disponível em:

$<$ http://www.faap.br/pdf/faculdades/economia/revistas/cienciaseconomicas/revista_economia_20.pdf>. Acesso em: 18 ago. 2016.

ASSAF NETO, Alexandre. Estrutura e Análise de Balanços: Um enfoque Econômico-Financeiro. 11. ed. São Paulo: Atlas, 2015. 366 p.

BM\&FBOVESPA;. 2017. Disponível em: <http://www.bmfbovespa.com.br/pt_br/index.htm>. Acesso em: 07 mar. 2017.

BORIO, Claudio. The Financial Cycle and Macroeconomics: What have we learnt?. Bis Working Papers, Basileia, Suiça, v. 395, p.1-32, dez. 2012.

BRAGA, Hugo Rocha. Demonstrações Contábeis: Estrutura, Análise, e Interpretação. 6. ed. São Paulo: Atlas, 2009. 238 p.

BRASIL. Lei 11.638, de 28 de dezembro de 2007. 
BRASIL. Lei 6.404, de 15 de dezembro de 1976.

BRESSER-PEREIRA, Luiz Carlos. Crise e Recuperação da Confiança. Revista de Economia Política, São Paulo, v. 29, p.133-134, jan. 2009. Trimestral.

CASTRO, Francisco. A força e importância da construção civil na economia brasileira. Disponível em:

<http://www.amapadigital.net/francisco_castro_view.php?ID=1415>. Acesso em: 18 ago. 2016.

CLAESSENS, Stijn; KOSE, M. Ayhan; TERRONES, Marco E.. Financial Cycles: What? How? When? 2011. Disponível em:

<http://www.imf.org/external/pubs/ft/wp/2011/wp1176.pdf>. Acesso em: 31 out. 2016.

CONSTRUTORA Adolpho Lindenberg. 2017. Disponível em:

<http://www.grupoldi.com.br/empresa/adolpho>. Acesso em: 07 mar. 2017.

CPC - Comitê de Pronunciamentos Contábeis. CPC 00 (R1) - Estrutura Conceitual para Elaboração e Divulgação de Relatório Contábil-Financeiro. 2011a. Disponível em: <http://www.cpc.org.br/Arquivos/Documentos/147_CPC00_R1.pdf> Acesso em: 22 Ago. 2018.

CPC - Comitê de Pronunciamentos Contábeis. CPC 26 (R1) - Apresentação das Demonstrações Contábeis. 2011b. Disponível em:

<http://www.cpc.org.br/Arquivos/Documentos/312_CPC_26_R1_rev\%2012.pdf> Acesso em: 22 Ago. 2018.

CR2 Empreendimentos Imobiliários SA. 2017. Disponível em: <http://www.cr2.com.br/acr2.html>. Acesso em: 07 mar. 2017.

CREPALDI, Silvio Aparecido. Curso Básico de Contabilidade: Resumo da teoria, atendendo às novas demandas da gestão empresarial, exercícios e questões com respostas. 7. ed. São Paulo: Atlas, 2013. 360 p.

CYRELA Brazil Realty S.A Empreend e Part. 2017. Disponível em: <http://www.cyrela.com.br/sobre>. Acesso em: 07 mar. 2017.

D'ALMEIDA, Alexandre Rodrigues. A Estratégia Americana de Enfrentamento da Crise de 2008 e a Guerra Cambial. In: ENCONTRO INTERNACIONAL DA ASSOCIAÇÃO KEYNESIANA BRASILEIRA, 4., 2011, Rio de Janeiro. Rio de Janeiro: AKB, 2011. v. 1, p. 1 - 20.

D'ANDRÉA, Gabriella. Ações de consumo, cíclicas, de valor: conheça as duas características. 2012. Disponível em: <http://www.infomoney.com.br/ondeinvestir/acoes/noticia/2506841/acoes-consumo-ciclicas-valor-conheca-suascaracteristicas>. Acesso em: 09 mar. 2017.

DIRECIONAL Engenharia S.A. 2017. Disponível em: <https://www.direcional.com.br/institucional>. Acesso em: 07 mar. 2017.

DUARTE, Helen Cristina Ferreira; LAMOUNIER, Wagner Moura. Análise Financeira de Empresas da Construção Civil por comparação com índices-padrão. Enf.: Ref. Cont., Paraná, v. 26, n. 2, p.9-28, maio 2007. Quadrimestral. 
ESTADÃO. Pib cresce 2,3\% em 2013 puxado por agropecuária e investimentos. 2014. Disponível em: $<$ http://economia.estadao.com.br/noticias/geral,pib-cresce-2-3-em-2013-puxado-poragropecuaria-e-investimentos,178695e>. Acesso em: 15 abr. 2017.

EVEN Construtora e Incorporadora SA. 2017. Disponível em: <https://www.even.com.br/sobreEven>. Acesso em: 07 mar. 2017.

EZTEC Empreend e Participações S.A. 2017. Disponível em:

$<$ http://www.eztec.com.br/imoveis/A-

EZTEC?utm_source=google\&utm_medium $=$ cpc\&utm_campaign=EZ-V-P $>$. Acesso em: 07 mar. 2017.

FARID, Jacqueline; CHIARINI, Adriana. Economia brasileira cresce 5,4\% em 2007. 2008. Disponível em: <http://economia.estadao.com.br/noticias/geral,economiabrasileira-cresce-5-4-em-2007,138797>. Acesso em: 24 abr. 2017.

G1. Economia brasileira é marcada por desemprego e crise em 2016. 2016. Disponível em: <http://g1.globo.com/jornal-nacional/noticia/2016/12/economiabrasileira-e-marcada-por-desemprego-e-crise-em-2016.html>. Acesso em: 25 abr. 2017.

G1. O cenário muda e a construção civil volta a viver bom momento. 2017. Disponível em: <http://g1.globo.com/pr/campos-gerais-sul/especialpublicitario/residencial-alto-de-santa-maria/noticia/2017/04/o-cenario-muda-econstrucao-civil-volta-viver-bom-momento.html>. Acesso em: 27 abr. 2017.

G1. Retrospectiva 2007: Economia e Negócios. 2007. Disponível em: $<$ http://g1.globo.com/Noticias/Economia_Negocios/0,,MUL215305-9356,00RETROSPECTIVA+ECONOMIA+E+NEGOCIOS.html>. Acesso em: 05 abr. 2017.

GAFISA S.A. 2017. Disponível em: <https://www.gafisa.com.br/institucional/agafisa>. Acesso em: 07 mar. 2017.

GAION, Aparecida Vani Frasson. EVA® (Economic Value Added): Uma ferramenta de riqueza ao alcance de todos. 2001. 8 f. Dissertação (Mestrado) - Curso de Contabilidade e Controladoria, Universidade Norte do Paraná, Londrina, 2001. Disponível em: <http://avaliacaodeempresa.com.br/adm/uploads/104pdffonte_EVA.pdf>. Acesso em: 16 mar. 2017.

GRECO, Alvisio; GÄRTNER, Günther; AREND, Lauro. Contabilidade: Teoria e Prática Básicas. 2. ed. São Paulo: Saraiva, 2009. 536 p.

GRECO, Alvísio; AREND, Lauro. Contabilidade: Teoria e Prática Básicas. 3. ed. São Paulo: Saraiva, 2011. 546 p.

HALL, James A.. Accounting Information Systems. 8. ed. Mason: South Western, 2012. $840 \mathrm{p}$.

HELBOR Empreendimentos S.A. 2017. Disponível em: <http://www.helbor.com.br/quemsomos>. Acesso em: 07 mar. 2017.

HILLEBRANDT, Patricia M.. Economic Theory and the Construction Industry. 3. ed. Grã-bretanha: Macmillan, 2000. 
IBGE. Instituto Brasileiro de Geografia e Estatística. Indicadores : Pesquisa Nacional por Amostra de Domicílios Contínua Primeiro trimestre de 2017. Rio de Janeiro: 2017. $34 \mathrm{p}$.

IG. Construção civil enfrenta pessimismo e setor desaquecido, aponta pesquisa da CNI. 2016. Disponível em: <http://economia.ig.com.br/2016-10-25/construcaocivil.html>. Acesso em: 24 abr. 2017.

IUDICÍBUS, Sérgio de. Análise de Balanços. 10. ed. São Paulo: Atlas, 2013.

IUDÍCIBUS, Sérgio de et al. Contabilidade Introdutória. 11. ed. São Paulo: Atlas, 2011. $335 \mathrm{p}$.

JORNAL DO BRASIL. Retrospectiva 2014: O cenário econômico do ano da Copa e das eleições. 2014. Disponível em:

<http://www.jb.com.br/economia/noticias/2014/12/30/retrospectiva-2014-o-cenarioeconomico-do-ano-da-copa-e-das-eleicoes/>. Acesso em: 05 abr. 2017.

JHSF Participações S.A. 2017. Disponível em: <https://www.jhsf.com.br/a-empresa/> . Acesso em: 07 mar. 2017.

JIMÉNEZ, Carla; MENDONÇA, Heloísa. Pib de 2014 revela uma economia estagnada e queda de investimento. 2015. Disponível em:

<http://brasil.elpais.com/brasil/2015/03/27/politica/1427458565_874347.html>. Acesso em: 16 abr. 2017.

JOÃO Fortes Engenharia SA. 2017. Disponível em:

<http://www.joaofortes.com.br/institucional/historia.aspx>. Acesso em: 07 mar. 2017.

LINS, Luis Santos; FRANCISCO FILHO, José. Fundamentos e Análise das

Demonstrações Contábeis: Uma abordagem interativa. São Paulo: Atlas, 2012. 208 p.

LORENZI, Sabrina. Brasil vira página da crise com crescimento de 7,5\% em 2010. 2011. Disponível em: <http://economia.ig.com.br/brasil-vira-pagina-da-crisecom-crescimento-de-75-em-2010/n1238129743669.html>. Acesso em: 24 abr. 2017.

MARION, José Carlos et al. Monografia para os cursos de administração, contabilidade e economia. 2. ed. São Paulo: Atlas, 2010. 139 p.

MEGLIORINI, Evandir; SILVA, Marco Aurélio Vallim Reis da. Administração Financeira: Uma abordagem brasileira. São Paulo: Pearson Prentice Hall, 2009. 251 p.

MENDONÇA, Heloísa. Mercado Imobiliários vive seu ajuste e abre espaço para barganha em 2015. 2015. Disponível em:

<http://brasil.elpais.com/brasil/2015/04/01/politica/1427914453_617511.html>. Acesso em: 18 ago. 2016.

MICHEL, Maria Helena. Metodologia e Pesquisa Científica em Ciências Sociais: Um guia prático para acompanhamento da disciplina e elaboração de trabalhos monográficos. 2. ed. São Paulo: Editora Atlas S.a, 2009. 204 p.

MINSKY, Hyman P.. The Financial Instability Hypothesis. Working Paper, Annandale-on-hudson, v. 74, p.1-10, maio 1992. Mensal. 
MOREIRA, Edison Marques. Um olhar para a crise do PIIGS. Indicadores Econômicos Fee, Porto Alegre, v. 38, n. 2, p.7-16, out. 2010. Trimestral.

MRV Engenharia e Participações SA. 2017. Disponível em:

<http://www.mrv.com.br/institucional/>. Acesso em: 07 mar. 2017.

NOGUEIRA, Luís Artur. Os pontos altos e baixos da economia brasileira em 2010 na visão do Santander. 2010. Disponível em: <http://exame.abril.com.br/brasil/ospontos-altos-e-baixos-da-economia-brasileira-em-2010-na-visao-do-santander/> . Acesso em: 13 abr. 2017.

NOTICIAS MINUTO A MINUTO. Construção civil em crise: Prédios comerciais estão vazios em SP e RJ. 2017. Disponível em:

$<$ https://www.noticiasaominuto.com.br/economia/367819/construcao-civil-em-crisepredios-comerciais-estao-vazios-em-sp-e-rj>. Acesso em: 24 abr. 2017.

O VALOR e a importância da contabilidade em um ano de crise. 2016. Disponível em: $<$ http://www.jornalcontabil.com.br/o-valor-e-importancia-da-contabilidade-em-um-anode-crise/>. Acesso em: 15 abr. 2016.

PADOVEZE, Clóvis Luís; BENEDICTO, Gideon Carvalho de. Análise das

Demonstrações Financeiras. 2. ed. São Paulo: Thomson Learning, 2007. 285 p.

PDG Realty SA Empreend e Participações. 2017. Disponível em:

<http://www.pdg.com.br/sobre-pdg>. Acesso em: 07 mar. 2017.

PEREZ JUNIOR, José Hernandez; BEGALLI, Glaucos Antonio.Elaboração e Análise das Demonstrações Contábeis. 4. ed. São Paulo: Editora Atlas S.a, 2009. 284 p.

RAMOS, Albenides. Metodologia da Pesquisa Científica: Como uma monografia pode abrir o horizonte do conhecimento. São Paulo: Atlas, 2009. 246 p.

RIBEIRO, Osni Moura. Estrutura e Análise de Balanços Fácil. 9. ed. São Paulo: Atlas, 2011. $254 \mathrm{p}$.

ROCHA, André. As ações cíclicas e a análise fundamentalista. 2015. Disponível em: $<$ http://www.valor.com.br/valor-investe/o-estrategista/3868126/acoes-ciclicas-e-analisefundamentalista>. Acesso em: 09 mar. 2017.

RODOBENS Negócios Imobiliários SA. 2017. Disponível em:

<http://rodobensimoveis.com.br/empresa/>. Acesso em: 07 mar. 2017.

ROSSI Residencial sa. 2017. Disponível em:

<http://www.rossiresidencial.com.br/institucional/sobre-a-rossi>. Acesso em: 07 mar. 2017.

SANTOS, Roberto Fernandes dos. Introdução à Contabilidade: Noções

Fundamentais. São Paulo: Saraiva, 2006.

SAPORITO, Antonio. Análise e estrutura das demonstrações contábeis.Curitiba: Intersaberes, 2015. $304 \mathrm{p}$. 
SCHUMPETER, Joseph A.. Business Cycles: A Theoretical, Historical and Statistical Analysis of the Capitalist Process. Nova Iorque: Mcgraw-hill Book Company, 1939. $461 \mathrm{p}$.

SILVA, Alexandre Alcantara da. Estrutura, Análise e Interpretação das Demonstrações Contábeis. São Paulo: Atlas, 2007. 195 p.

TECNISA SA. 2017. Disponível em: 〈https://www.tecnisa.com.br/sobre-a-tecnisa>. Acesso em: 07 mar. 2017.

TEIXEIRA, Luciene Pires; CARVALHO, Fátima Marília Andrade de. A Construção Civil como instrumento do desenvolvimento da economia brasileira. Revista Paranaense de Desenvolvimento, Curitiba, n. 109, p.9-25, jul. 2005. Semestral.

TORRES, Ernani; PUGA, Fernando; MEIRELLES, Beatriz (Org.). Perspectivas do Investimento: 2010 - 2013. Rio de Janeiro: Bibioteca Digital Bndes, 2011. 356 p.

UOL. Economia brasileira cresce 5,4\% em 2007, aponta IBGE. 2008. Disponível em: <https://economia.uol.com.br/ultnot/2008/03/12/ult4294u1121.jhtm>. Acesso em: 16 abr. 2017.

VIVER Incorporadora e Construtora S.A. 2017. Disponível em: <http://www.viver.com.br/empresa>. Acesso em: 07 mar. 2017.

ZAREMBA, Júlia. Setor da Construção Civil se Organiza para Retomada nas Vendas. 2017. Disponível em:

<http://www1.folha.uol.com.br/sobretudo/morar/2017/04/1871791-setor-da-construcaocivil-se-organiza-para-retomada-nas-vendas.shtml> . Acesso em: 29 maio 2017. 